\title{
Post-Project Environmental Impact Evaluation of Ota Industrial Housing Estate on the Localized Environment and Environs in Ogun State, Nigeria
}

\author{
*Peter Ibhadode ${ }^{1}$ A. P. Ibhadode ${ }^{2}$ Osagie Ibhadode $^{3}$ O. M. Sosanolu ${ }^{4}$ \\ Independent Researcher and Safety, Health \& Environmental (SHE) Officer ${ }^{1,2}$; Research Engineer ${ }^{3}$, \\ Research Officer ${ }^{4}$ \\ *Hafalix Nigeria Limited, Port Harcourt, Nigeria ${ }^{1}$ \\ IHE Delft Institute of Water Education, Delft, The Netherland ${ }^{2}$ \\ Cintojon Company (Nigeria) Limited, Ota-Lagos, Nigeria ${ }^{2}$ \\ Nigerian Building and Road Research Institute (NBRRI), Abuja, Nigeria ${ }^{3,4}$
}

\begin{abstract}
In this research paper, twelve (12) consecutive weekly field-studies were carried-out within a study-period of three (3) months to determine the current baseline environmental data of the study-area-'Ota Industrial Housing Estate and Environs' by conducting a Post-Project Environmental Impact Evaluation (EIE) of the Estate's industrial wing on its residential wing-which was divided into three Catchments (Catchment 1, Catchment 2 and Catchment 3) in addition to Catchment 4 (i.e. its Environs) which is a proximal neighbouring community to the study-area called 'Obasanjo locality'. Consequently, standard experimental procedures were engaged to determine the baseline data values of the selected biophysiochemical environmental parameters of the study area, which were then compared with the values obtained at the Control-environment [i.e. 'Atan locality' which is a distant community located about $15 \mathrm{~km}$ from the study-area] and/or with the benchmark values/limits recommended by global and national standardizing bodies (organizations) [such as the 'WHO', 'ISO', 'OSHA', 'ASTM', 'APHA', 'DPR', 'SON' and 'FMEnv'] for human safety. Based on the experimental results obtained, some of the inferences made are summarily stated below. Majority of the measured microclimatic, acoustic and outdoor air quality parameters are higher than the standard recommended limits and the control environment's values. The Soil Nutrients' and Heavy metals' concentrations are randomly distributed. The predominant land-use type is 'Residential' while the least is 'Educational'. The predominantly occurring vegetation is 'Elephant grass (Botanical name: Permisetum Purpuretum)'. Apart from pH , Electrical Conductivity, Temperature, Dissolved Oxygen (DO) and Biochemical Oxygen Demand(BOD), all the other Groundwater quality assessment parameters are higher than the standards' recommended limits. Thus, the industrial wing of 'Ogun State Industrial Housing Estate' environmentally impacts its residential wing and environs negatively.
\end{abstract}

Key Words: Environmental Impact Evaluation, Pollution, Human Safety, Air Quality, Groundwater.

\section{INTRODUCTION}

There is no doubt that in most developing countries, certain national developmental strides (achievements) such as increased industrial productivity, mining activities and exploration of natural resources etc.; which are aimed at achieving local consumerproduct sufficiency and balancing bilateral trade deficits with other nations, also come with adverse environmental impacts. More often than not, in most cases of unregulated industrialization, mining and natural resource exploration etc., the environment is at the receiving end, with man bearing the brunt, by paying the ultimate price with his health - due to the numerous associated hazardous environmental conditions including: Noise pollution [1], [2], [3]; low outdoor Air Quality Index [4], poor natural ventilation performance [5], inadequate indoor illumination [6], consumption of contaminated water [7] and [8], indoor exposure to radiological hazards from unexpected sources like building materials [9] and indiscriminate industrial waste disposal [10], [11], [12] [13], which can be significantly controlled by the safe recycling of wastes to transform them into useful products [14] and [15]. At the moment, these and a number of other factors are considered to be of critical importance, as both the Natural and the Built environmental experts clearly harp on the need to have them factored-in them in before, during and after the design and execution of developmental projects [16] and [17]; while prioritizing eco-friendly project execution methods \& strategies over others [18]. 
It is in view of the above expressed concerns and a host of other considerations that the push for legislations enforcing the mandatory adoption of 'Environmental Impact Assessment (EIA)' gradually began to receive a boost in several nations across the globe. Simply put, Environmental Impact Assessment (EIA) is a vital instrument that has a legal framework and consists of a sequence of carefully planned processes aimed at ensuring that developmental projects conform to the conditions of environmental sustainability. More comprehensively, EIA is such an indispensable tool which becomes helpful in evaluating the environmental effect(s) of proposed developmental projects, which are first visualized and are then controlled by the careful formulation of mitigation strategies amongst others.

According to [19], 'EIA' is a study of the impacts of a planned project or programme on the environment. EIA is a study carriedout so as to predict the effect(s)/consequence(s) of a proposed project on the environment [20]. EIA is that tool, which helps to prevent or mitigate occurrence of any adverse environmental effect/impact that would have been associated with the execution of socio-economic developmental projects [21]. The International Association for impact Assessment 'IAIA' is of the opinion that, EIA is a holistic process which involves the identification, prediction, evaluation and mitigation of the biophysiochemical, socioeconomic and other associated effects of a proposed developmental project, prior to making critical decisions and financial commitments toward it [22].

Dating back to 1970, the very first national legislation to be enacted on EIA in world history took place in the United States of America (USA) — with the establishment of the national environmental policy act. However, it was the 1972 United Nations (UN) conference on 'the Environment' which held in Stockholm, Sweden, that actually set-the-ball-rolling by globally formalizing the concept of 'EIA' in several economically-viable countries including Canada, New Zealand and Australia etc., [19] and [20]. This was immediately after the decade-long informal era of EIA in the 1960s [23].

Although, the numerous short-term and long-term inherent benefits (advantages) of EIA make it a laudable programme worldwide, yet, there still seems to be demerit (disadvantage) that it is limited to only 'proposed developmental projects'—clearly excluding the 'already existing developmental projects' and their associated effects on the localized environment. Furthermore, an extensive survey of the currently existing literature show that the subject of discussion (interest) have always been proposed (future, planned) projects, and not the already existing (present) project. There is therefore the need to embark on an EIA-related study which focuses on the already existing (present) developmental projects-which we have coined "Post-Project Environmental Impact Evaluation (EIE)". Our Case-study will be 'Ota Industrial Housing Estate'—which is located at Kilometer 6 Ota-Idiroko Road, in Ota town (municipality) of Ogun State, South-Western Nigeria. The decision to adopt this estate as the case-study is based on its peculiar predominantly hybrid land-use pattern-i.e. partly industrial on one side and partly residential (housing) on the other side. Consequently, the aim of this study is to determine the current baseline environmental data of the study-area-'Ota Industrial Housing Estate and Environs', by carrying-out a Post-Project Environmental Impact Evaluation of its Industrial Wing on its Residential Wing and Environs.

\section{MATERIALS AND METHOD}

The Study-area is 'Ota Industrial Housing Estate and its environs (Obasanjo locality)' situated between Lat. 6.6927 $\mathrm{N}$ $6.6927^{\circ} \mathrm{N}$ and Long. $3.2365^{\circ} \mathrm{E} 3.2365^{\circ} \mathrm{E}$ along the busy 'Ota-Idiroko International Expressway (road)' in Ota municipality - a densely populated and highly industrialized town in Ado-Odo/Ota Local Government Area of Ogun State, SouthWestern Nigeria. Established as far back as 1983 by then Olabisi Onabanjo-led government of Ogun State to simultaneously serve the dual purpose of industrialization (production) and housing. Covering an approximate land mass area of $22.8 \mathrm{Km}^{2}$, it was ranked as one of the largest Industrial Estates in the country in the early eighties. Apart from accommodating a gradually rising number of privately-owned residential houses, 'Ota Industrial Housing Estate' is the carefully planned spacious home (operational base) of a large number of manufacturing companies whose business operations include the production of distilled beverages (spirits), galvanized pipes, cooking utensils chemical products (resins, dyes, solvents, reagents, paints), roofing sheets, high \& medium yield steel bars (rods) for concrete reinforcement and pharmaceutical products; in addition to Scrap-metal recycling to produce metallic products particularly Aluminum and Steel-based products. Also, located some $15 \mathrm{Km}$ away from the study-area is the Control-environment which is known as 'Atan community' and is situated between Lat. 6.6864' $\mathrm{N}$ and Long. $3.0676^{\circ} \mathrm{E}$ also along Ota-Idiroko Express road; and is a predominantly residential and highly populated locality. This reasonably long distance apart, makes Atan community free from (i.e. unaffected by) the environmental effects (hazards) associated with the industrial activities of the manufacturing (production) companies operating in the study-area-Ota Industrial Housing Estate. Thus, this makes Atan community an ideal Control-environment for this study. 
The Estate is divided into two (2) wings by the main entrance/exit road [called the 'Industrial Road'] which stretches inward from the main entrance gate and terminates at a point before its rear boundary (perimeter fence). One wing is known as the 'Industrial Wing' — which basically accommodates industries, while the other wing is known as the 'Residential Wing'—which basically accommodates residential (housing) apartments. For the purpose of this study, the Residential Wing has been divided into three Catchments at various distances from the Industrial wing i.e. Catchment 1: 'Estate Residential Wing Zone 1' [at 20m from the Industrial Wing], Catchment 2: 'Estate Residential Wing Zone 2' [at 70m from the Industrial Wing], and Catchment 3: 'Estate Residential Wing Zone 3' [at 120m from the Industrial Wing]. Also, Catchment 4 is 'Obasanjo locality', which is a densely populated human settlement that hosts the 'Obasanjo Livestock Farm', and is located outside the Estate at a distance of about $200 m$ from the Estate's industrial road. As was previously noted, the Control-environment is called 'Atan locality'—which is a fairly distant, densely populated and predominantly residential human settlement that is located at about $15 \mathrm{Km}$ (i.e. $15000 \mathrm{~m}$ ) from the Estate's industrial road.

It is important to mention that, these divisions became necessary based on the existing geographical delineations, and the constant overlap of socio-economic activities within the Estate's Catchments. Furthermore, this was done in order to carefully disintegrate the relatively large study-area into four small and easy-to-cover study-units (catchments); while specifically taking into cognizance the unique characteristic features of each of these four Catchments, after which, they were then compared with the features of the Control-environment and/or some standard limits.

In order to obtain experimental data for some of the most relevant biophysiochemical environmental parameters, the investigation team embarked on twelve (12) weekly field studies followed by rounds of periodic laboratory analyses on selected ecological characteristics [i.e. Pedology (Soil Science), Climate, Acoustics, Air quality, Land use, and Vegetation] of the Study-area and the Control-environment. The field studies were periodically carried-out twelve times at each catchment and the Control-environment between 7am (07:00hours) and 6 pm (18:00hours) for a study period of three (3) months from January to March 2019. After which, the average values of the investigated parameters were obtained and adopted as the representative data.

When and where it was deemed necessary to collect test samples for analysis, the collection, storage, handling and analytical testing of test-samples were carried-out in accordance with relevant standards and guidelines specified by Nigeria's Federal Ministry of Environment 'FMEnv' (1995) [24] and the Department of Petroleum Resources 'DPR' (2002) Guidelines and Standards (Part VIII, D2, Sampling and Handling of Samples) [25] and [26] to the limits of possibility. Also, other globally and nationally recognized scientific analytical Guidelines and Standards [such as the International Standards Organization (ISO) [27] and [28] World Health Organization (WHO) [29], American Society for Testing and Materials (ASTM), American Public Health Association ( $A P H A)$ and the Standards Organization of Nigeria (SON)] were adopted procedurally as necessitated. Prior to the actual commencement of field and laboratory data sourcing, all equipment that required calibration were duly calibrated based on the manufacturers' recommendations.

On the start date of the field surveys, microclimatic meteorological stations were set-up in the Control-environment and within Study-area's four (4) catchments i.e. Catchment 1, Catchment 2, Catchment 3 and Catchment 4-at respective approximate distances of $20 \mathrm{~m}, 70 \mathrm{~m}, 120 \mathrm{~m}$ and $200 \mathrm{~m}$ from the industrial road which serves as the boundary between the residential area and industrial area of the estate. During each of the twelve (12) field surveys conducted, experimental data for an acoustic parameter [i.e. Ambient Noise Level ' $A N L$ ']; four microclimatic parameters (properties) [Air temperature, Wind speed, Wind direction \& Relative humidity] and three Outdoor Air Quality parameters (OAQ) [Carbon (II) Oxide, Nitrogen (IV) Oxide, and Sulphur (IV) Oxide] were obtained. The Ambient Noise Level was measured with the aid of a handheld CR811C Noise meter at an altitude of $1.5 \mathrm{~m}$ above the ground, Outdoor Air Quality was measured using an 'Aeroqual AQM 65 Ambient Air monitoring station', and Relative Humidity was measured with the aid of an 'AcuRite 00613A1 top-digital Hygrometer' while the other measured micro-climatic parameters (i.e. Air temperature, Wind speed \& Wind direction) were measured/obtained using a 'WM - 200 Windmate Wind-meter'.

The Pedology (Soil study) was carried-out on five (5) surface soils [ $0.0-15.0 \mathrm{~cm}$ ] in each of the four (4) catchments of the Study-area and the Control-environment. Then, using a probe auger, each of twenty-five (25) tested surface soils were compositely sampled. Thus, this was done to determine the following: Soil $p H$ using a Hannah $p H$ Meter, Soil Electrical Conductivity using a Hannah Electrical-Conductivity Meter, Soil nutrients $\left[\mathrm{Na}^{+}, \mathrm{K}^{+}, \mathrm{Ca}^{2+}\right.$ and $\left.\mathrm{Mg}^{2+}\right]$ analyses using a 
'Beckman model DU flame AAS', and Soil Heavy-metal content using a 'Perkins Elmer model 306 Atomic Absorption Spectrophotometer $(A A S)$ ' after Concentrated Trioxonitrate $(V)\left[\mathrm{HNO}_{3}(a q)\right]$ acid digestion.

In order to evaluate the various Land-use types, the frequency of each land use application i.e. 'Residential', 'Educational/Academic (School)', 'Religious (Church/Mosque)', Agricultural (Subsistence/peasant Farming)', 'NonManufacturing Business' and 'Un-Used' were determined; and then, expressed as percentages relative to one another.

The Random Quadrant Sampling Method was adopted to study the Vegetation at each Catchment. While herbs were studied using a ' $1 m$ by $1 m$ ' quadrant, the shrubs and trees were studied using a ' $10 m$ by $10 m$ ' quadrant. The plant species in each of the two quadrants were identified. Counting was done to ascertain the population density of all ecosystem-significant dominant and rare/endangered plant and tree species \& the herbaceous layer with the grasses included [30] and [31]. In accordance with Reference [32], the importance value of a plant species was specifically defined [for this research investigation], as the total number of individuals present in each quadrant. After which, the diversity of each plant species was determined to be the quotient obtained from the division 'Number of plant species' as dividend and 'Importance value of plant species' as divisor. In each of the Catchments, the spectrum of the life form of each available plant group was then analyzed with 'Raunkerian Life Form Classification System' [30] and [33], as follows:

(a) Phanerophytes:

i. Trees whose heights ranged between $8.0 m$ and $30.0 m$, referred to as 'Mesophanerophytes', and abbreviated as ' $M_{e p}$ '

ii. Trees and Shrubs whose heights ranged between $2.0 m$ and $8.0 m$, referred to as 'Microphanerophytes', and abbreviated as ' $M_{i p}$ '

iii. Shrubs whose heights were below $2.0 \mathrm{~m}$, referred to as 'Nanophanerophytes', and abbreviated as ' $N_{o p}$,

(b) Yearly growing plants, referred to as 'Therophytes', and abbreviated as 'The'

(c) Plants such as Tubers \& Rhizomes etc., whose surviving buds lay (lie) underneath the ground referred to as 'Cryptophytes', and abbreviated as ' $\mathrm{Cry}$ '

(d) Plants such as Climbers etc., whose surviving buds lay (lie) above the ground, referred to as 'Chamaephytes', and abbreviated as ' $C h a$ '

(e) Plants whose surviving buds are on the ground, referred to as 'Hemicrytophytes', and abbreviated as ' Her'.

Groundwater samples were collected from five (5) randomly selected boreholes sunk in each Catchment of the Study-area using 10-litre sterile plastic jerricans (containers) sealed and stored in refrigerators at $4^{\circ} \mathrm{C}$ prior to laboratory testing. Each of the five collected groundwater samples per catchment was divided into three portions. The first portion was used for physio-chemical \& mineral content analyses, the second portion which was first digested with Concentrated Trioxonitrate $(\mathrm{V})\left[\mathrm{HNO} \mathrm{O}_{3}(a q)\right]$ acid was used for heavy metal content analysis and the third portion was used for microbiological analysis.

Thus, for each of the first portions of the five collected groundwater samples per Catchment, the Temperature, Electrical Conductivity, Turbidity and $p H$ were measured with the aid of a 4510 model Jenway Conductivity Meter, a Hanna H198703 Turbidimeter and a Hanna H199192 Thermometer and $p H$ dual functional meter respectively; while Salinity, Biochemical Oxygen demand (BOD), Alkalinity and Total Hardness were measured in accordance with the relevant ASTM test methods [34].

Also, the Magnesium $\left(\mathrm{Mg}^{2+}\right)$, Potassium $\left(\mathrm{K}^{+}\right)$, Sodium $\left(\mathrm{Na}^{+}\right)$and Nitrate $\left(\mathrm{NO}_{3}^{-}\right)$contents were obtained in accordance with the applicable ASTM test methods [35], [36], [37] [38]; Calcium ( $\left.\mathrm{Ca}^{2+}\right)$ content was measured using the EDTA (Ethylene Dinitrilo Tetra-acetic Acid) method; and Sulphate $\left(\mathrm{SO}_{4}^{2-}\right)$ content was determined using the Colorimetric analysis method; while the American Public Health Associations (APHA) gravimetric test methods were employed to determine the Total Dissolved Solids $(T D S)$, Total Suspended Solids $(T S S)$ and Total Solids $(T S)$ [39]; and then, the Chloride $\left(\mathrm{Cl}^{-}\right)$content and Dissolved 
Oxygen $(D O)$ were respectively obtained using the 'Mohr Method' and the 'Wrinkler's Analytical Method for Dissolved Oxygen Determination' [39] and [40].

Then, using the second portions of the five collected groundwater samples per Catchment, [which had been previously digested with conc $\mathrm{HNO}_{3}(a q)$ ], the detection of the possible presence of, and the actual measurement of the concentrations of the various heavy metals present, was performed with the aid of a 'Perkins -Elmer model 306 Atomic Absorption Spectrophotometer $(A A S)$ ' in a chemical testing laboratory operated by 'Fatlab Nigeria Company', situated at $28^{\text {th }}$ Oyo Road, close to the University of Ibadan, Ibadan City, Oyo State, South-Western Nigeria.

Moreover, using the third portions of the five collected groundwater samples per Catchment, the United States environmental Protection Agency's (USEPA) specified' Membrane Filtration Method for Micro-organism Analytical Testing of Water' was used to identify and obtain the Count (i.e. quantity in 'Counts per $100 \mathrm{~mL}$ ') of bacterial micro-organism(s) that were present in the groundwater samples [43] and [44].

Finally, the experimental data/results so obtained were collated and directly compared with certain benchmark data values/ranges obtained from the relevant international and/or national regulatory Standard limits. However, in cases/instances where this was not possible, comparison with the Control-experimental data values/ranges - i.e. comparison with data vales/ranges obtained after conducting same Experimental test(s) in the Control-environment was resorted to. Then, both sets of data (i.e. Experimental data/results and Benchmark data/Control-experimental data) were used to plot illustrative charts, so as to graphically evaluate the magnitude of their conformity/Non-conformity with the relevant Standard limits/ranges (recommended by the 'WHO' , 'ISO', '

'ASTM', 'DPR', 'APHA', 'SON' and 'USEPA' ) \{[29]; [27] and [28]; [34], [35], [37] and [38]; [24]; [25] and [26]; [39]; [40]; [41] and [42]; [43] and [44]\} in addition to their similarity(ies)/variation(s) from the value(s) obtained (measured/computed) at the Control-environment which is located at about fifteen kilometers $(15 \mathrm{Km})$ from the study-area i.e. 'Ogun State Industrial Housing Estate' in Ota municipality of Ado-Odo/Ota Local Government Area, South-Western Nigeria.

\section{RESULTS AND DISCUSSION}

During the three-month study period from January - March 2019, it was observed from Figure 1 that, the prevailing wind direction in the study-area was North-Easterly (NE) [i.e. originating from the North-East direction]; while the wind-speed ranged from $12.3 \mathrm{~m} / \mathrm{s}$ to $13.4 \mathrm{~m} / \mathrm{s}$ and averaged at $12.8 \mathrm{~m} / \mathrm{s}$ as against the wind-speed in Control-environment—which stood at a higher value of $13.6 \mathrm{~m} / \mathrm{s}$. Now, it could be noticed that, the farther the distance from the Estate's Industrial Wing, the higher the wind-speed. This is because, the lowest wind-speed of $12.3 \mathrm{~m} / \mathrm{s}$ was recorded at Catchment 1 ['Estate's Residential Wing Zone 1'] which is the nearest to the Estate's Industrial Wing, at a distance of $20 m$ while the highest wind-speed of $13.4 m / s$ was recorded at Catchment 4 [at Catchment 4 i.e. 'Obasanjo Residential Community' which is outside the estate and is] the farthest to the Estate's Industrial wing, at a distance of 200m .Also, during this study period while the ambient Air temperature range stood at $29.0-31.4^{\circ} \mathrm{C}$ with an average of $30.7^{\circ} \mathrm{C}$; the Relative Humidity range stood at $67-70 \%$ with an average value of $69 \%$. Here again, the farther the distance from the Estate's Industrial Wing, the lower the ambient Air temperature and Relative humidity, as could be seen from Figure 1.

As is illustrated in Figure1, the measurement of ambient Noise-levels within each of the four (4) that are varying distances from the Estate's Industrial Wing showed that: the highest ambient Noise-level ranged from $57-112 d B(A)$ with an average value of $75 d B(A)$ as against the Control environment's ambient Noise-level of $45 d B(A)$ and the ' ISO1996-1' and ' ISO1996-2 ' recommended maximum outdoor ambient Noise-level of $55 \mathrm{~dB}(A)$ to prevent sleep-disturbance, speech-unintelligibility, and noise-annoyance etc., within the study-area [27] and [28]. Regrettably, in Catchment 1 (i.e. 'Estate's Residential Wing Zone 1') which is barely $20 \mathrm{~m}$ from the Estate's Industrial Wing, a dangerously high ambient Noise-level of $112 d B(A)$ was recorded-a value which significantly exceeds the $W H O$ recommended maximum ambient Noise-level of $90 \mathrm{~dB}(A)$ for $8 h o u r$ daytime safe human exposure. Again, it could be seen from the chart in Figure 1 that, the ambient Noise-levels increased with increasing distance from the Estate's Industrial Wing. 


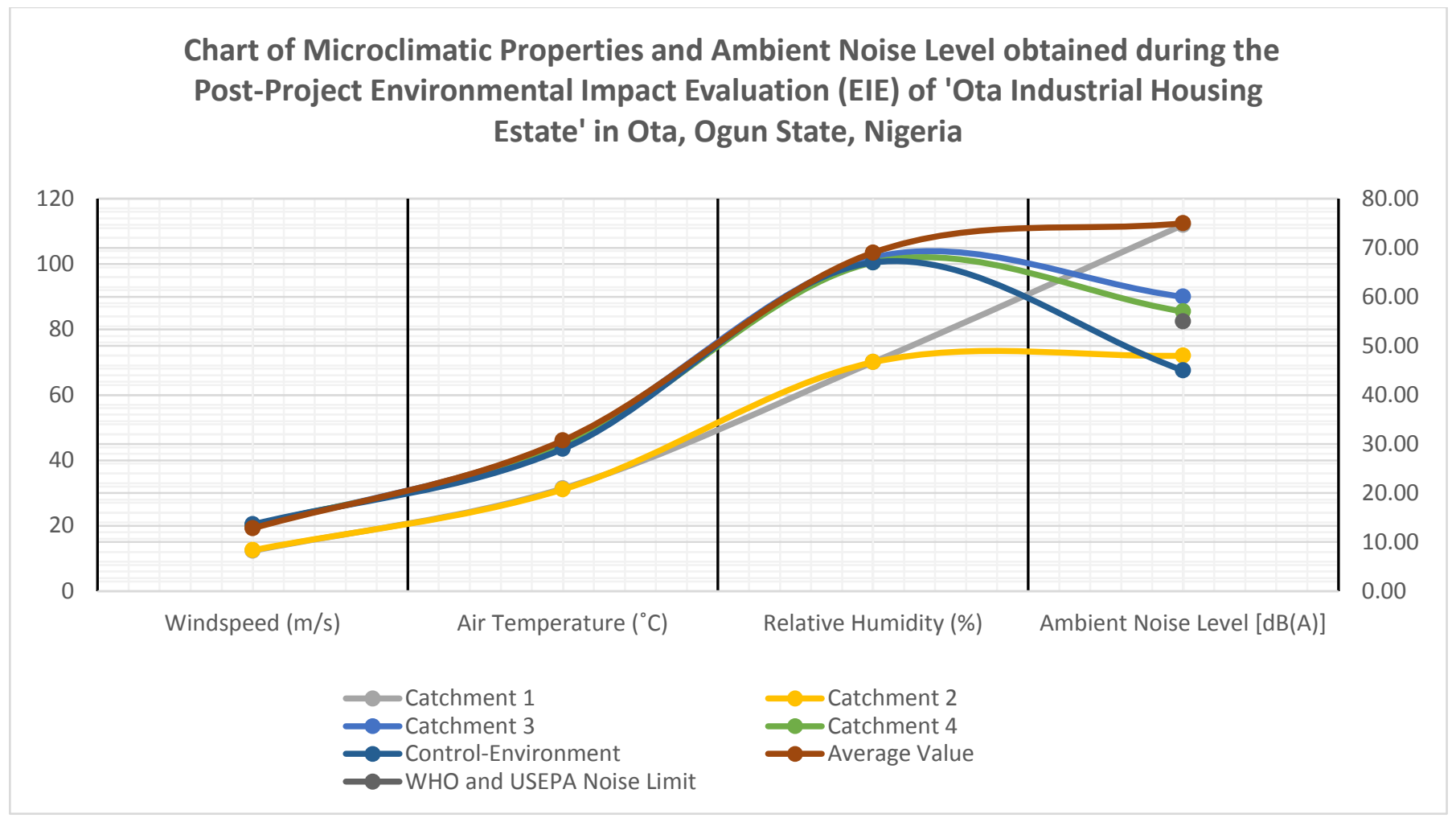

Figure 1: Chart of Microclimatic Properties and ambient Noise Level obtained during the Post-Project Environmental Evaluation (EIE) of 'Ota Industrial Housing Estate' in Ota, Ogun State, Nigeria

Graphically illustrated in Figure 2 is the result of the outdoor Air Quality monitoring within the four (4) Catchments in the studyarea and the Control-environment [with respect to three (3) common atmospheric pollutants i.e. Carbon (II) Oxide ' $C O(g)$ ', Nitrogen (IV) Oxide ' $\mathrm{NO}_{2}(g)$ ' and Sulphur (IV) Oxide ' $\mathrm{SO}_{2}(g)$ '], from which the following were observed:

(a) The $C O(g)$ concentrations ranged from $9.6 m g / m^{3}$ [at Catchment 4 i.e. 'Obasanjo Residential Community' which is outside the estate and is the farthest to the Estate's Industrial wing, at a distance of $200 \mathrm{~m}$ ] to $21.3 \mathrm{mg} / \mathrm{m}^{3}$ [at Catchment 1 i.e.' Estate's Residential Wing Zone 1' which is nearest to the Estate's Industrial wing at a distance of $20 \mathrm{~m}$ ], with an average value of $15.7 \mathrm{mg} / \mathrm{m}^{3}$. These values are higher than the Control-environments' $C O(g)$ concentration of $3.5 \mathrm{mg} / \mathrm{m}^{3}$ and the $\mathrm{WHO}$ maximum recommended $\mathrm{CO}(\mathrm{g})$ limit of $5.8 \mathrm{mg} / \mathrm{m}^{3}$-a chronic lowlevel exposure condition which according to [29] is most likely to result in 'deficiency in memory' with respect to mental activities, unusual cardiac activities and emotional psychiatric changes etc., in humans living within the study-area.

(b) The $\mathrm{NO}_{2}(\mathrm{~g})$ concentrations ranged from $28.4 \mu \mathrm{g} / \mathrm{m}^{3}$ (Catchment 4 i.e. 'Obasanjo Residential Community' outside the estate) to $39.3 \mu \mathrm{g} / \mathrm{m}^{3}$ (Catchment 1 i.e. 'Estate's Residential Wing Zone 1'), with an average values of $33.6 \mu \mathrm{g} / \mathrm{m}^{3}$ — which is approximately the $\mathrm{NO}_{2}(\mathrm{~g})$ concentration obtained at Catchment 2 i.e. 'Estate's Residential Wing Zone 2'. Although, these values are higher than the Control-environment's $\mathrm{NO}_{2}(g)$ concentration of $22.5 \mu \mathrm{g} / \mathrm{m}^{3}$, yet they are safely lower than the $\mathrm{WHO}$ maximum recommended $\mathrm{NO}_{2}(\mathrm{~g}) \operatorname{limit}$ of $200.0 \mu \mathrm{g} / \mathrm{m}^{3}$ for one (1) hour exposure to prevent respiratory health disorders in humans [29]. 


\section{Chart of Outdoor Air Pollutants' Concentrations obtained during the Post-Project Environmental Impact Evaluation (EIE) of 'Ota Industrial Housing Estate' in Ota, Ogun State, Nigeria}

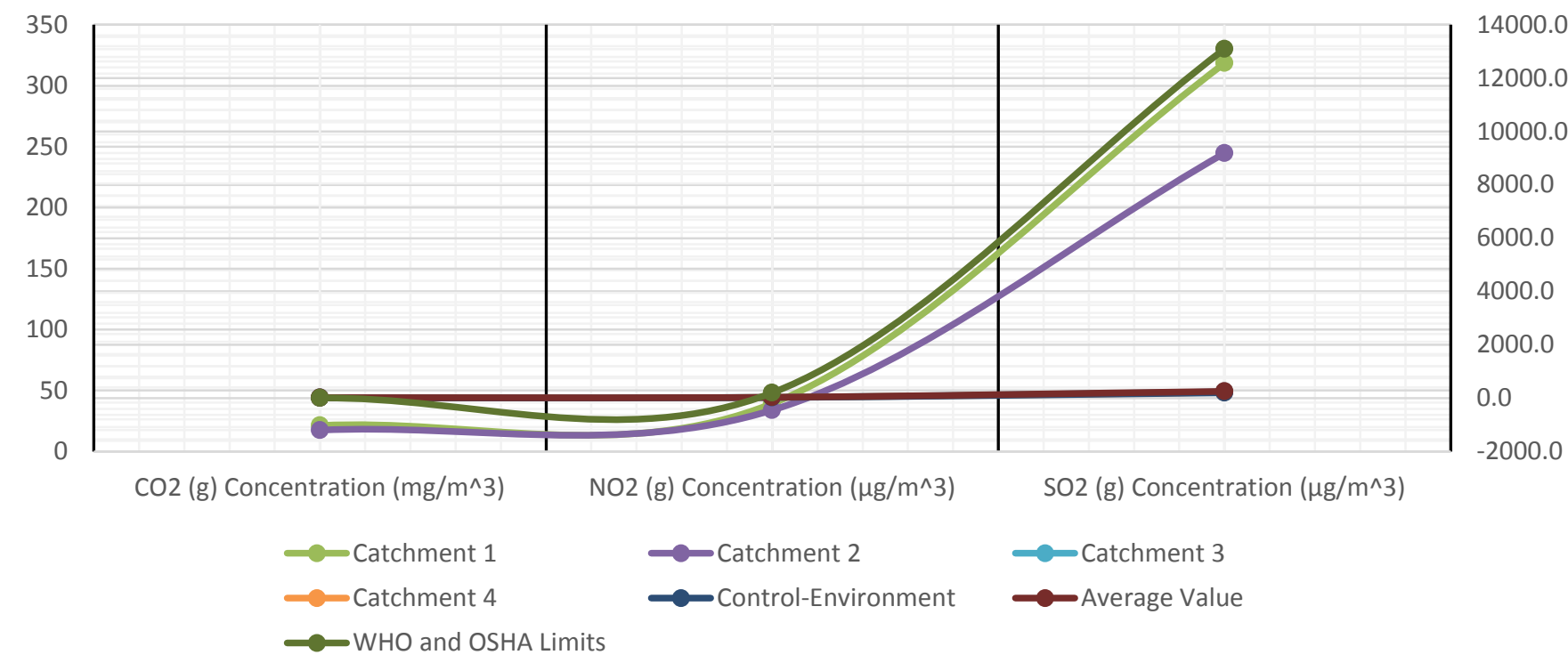

Figure 2: Chart of Outdoor Air Pollutants' concentrations obtained during the Post-Project Environmental Evaluation (EIE) of 'Ota Industrial Housing Estate' in Ota, Ogun State, Nigeria

(c) The $\mathrm{SO}_{2}(\mathrm{~g})$ concentrations ranged from $216.0 \mu \mathrm{g} / \mathrm{m}^{3}$ (Catchment 4 i.e. 'Obasanjo Residential Community' outside the estate) to $318.5 \mu \mathrm{g} / \mathrm{m}^{3}$ (Catchment 1 i.e. 'Estate's Residential Wing Zone 1') with an average value of $253.8 \mu \mathrm{g} / \mathrm{m}^{3}$. These values are higher than the control-environment's $\mathrm{SO}_{2}(\mathrm{~g})$ concentration of $200.0 \mu \mathrm{g} / \mathrm{m}^{3}, \mathrm{but}$ higher the OSHA 8hour Permissible Exposure limit of $13096.0 \mu \mathrm{g} / \mathrm{m}^{3}$ (5 ppm) to prevent sneezing, coughing and Bronchospasm [29].

Figure 3 captures the concentrations of four (4) selected soil nutrients-Sodium $\left(\mathrm{Na}^{+}\right)$, Potassium $\left(\mathrm{K}^{+}\right), \mathrm{Calcium}\left(\mathrm{Ca}^{2+}\right)$ and Magnesium $\left(\mathrm{Mg}^{2+}\right)$ found to be present in the soils of the Control-environment and the four (4) Catchments that comprised the study-area. The Sodium $\left(\mathrm{Na}^{+}\right)$soil nutrient concentrations recorded within the study-area ranged from $0.57 \mathrm{meq} / 100 \mathrm{~g}$ (Catchment 2) to $0.93 \mathrm{meq} / 100 \mathrm{~g}$ (Catchment 1 ) and averaged at $0.78 \mathrm{meq} / 100 \mathrm{~g}$ - significantly less than the concentration at 'Catchment 4'; while a sodium concentration of $0.64 \mathrm{meq} / 100 \mathrm{~g}$ was recorded at Control-environment.

The Potassium $\left(\mathrm{K}^{+}\right)$soil nutrient concentrations recorded within the study-area ranged from $0.33 \mathrm{meq} / 100 \mathrm{~g}$ (Catchment 2) to $0.62 \mathrm{meq} / 100 \mathrm{~g}$ (Catchment 4 ) and averaged at $0.45 \mathrm{meq} / 100 \mathrm{~g}$, while a potassium concentration of $0.40 \mathrm{meq} / 100 \mathrm{~g}$ was recorded at Control-environment.

The Calcium $\left(\mathrm{Ca}^{2+}\right)$ soil nutrient concentrations recorded within the study-area ranged from $0.18 m e q / 100 \mathrm{~g}(\mathrm{Catchment} 2)$ to $0.31 \mathrm{meq} / 100 \mathrm{~g}$ (Catchment 3) and averaged at $0.23 \mathrm{meq} / 100 \mathrm{~g}$ - slightly lesser than the concentration at 'Catchment 1 '; while a Calcium concentration of $0.22 \mathrm{meq} / 100 \mathrm{~g}$ was recorded at the Control-environment.

The Magnesium $\left(\mathrm{Mg}^{2+}\right)$ soil nutrient concentrations recorded within the study-area from $0.10 \mathrm{meq} / 100 \mathrm{~g}$ (Catchment 1 and Catchment 4) to $0.13 \mathrm{meq} / 100 \mathrm{~g}$ (Catchment 2) and averaged at $0.11 \mathrm{meq} / 100 \mathrm{~g}$ - the exact same concentration recorded at 'Catchment 3'); while a Magnesium concentration of $0.12 \mathrm{meq} / 100 \mathrm{~g}$ was recorded at the Control-environment. 
Chart of Soil Nutrients' Concentrations obtained during the Post-Project Environmental Impact Evaluation (EIE) of 'Ota Industrial Housing Estate' in Ota, Ogun State, Nigeria

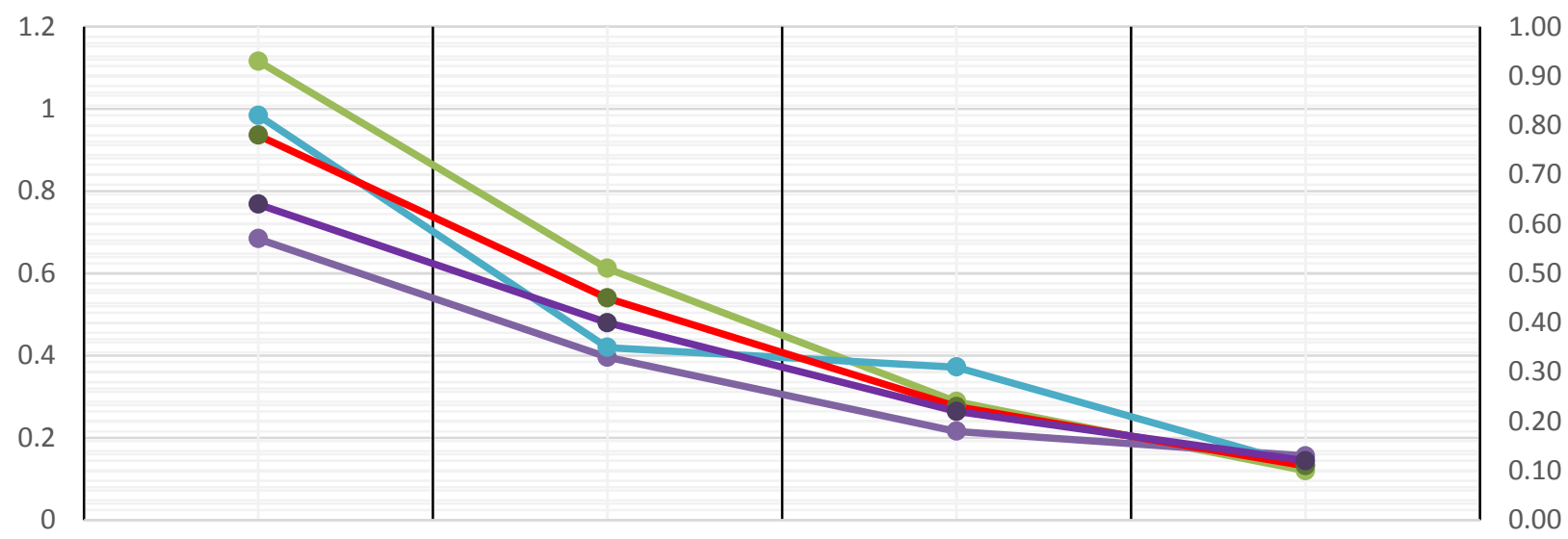

Sodium 'Na+' Soil Nutrient Potassium 'K+' Soil Nutrient Calcium 'Ca2+' Soil Nutrient Magnesium 'Mg2+' Soil Concentration (meq/100g) Concentration (meq/100g) Concentration (meq/100g) Nutrient Concentration (meq/100g)

- Catchment $1 \longrightarrow$ Catchment $2-$ Catchment $3-$ Average Value $\longrightarrow$ Control-Environment

Figure 3: Chart of Soil Nutrients' Concentrations obtained during the Post-Project Environmental Evaluation (EIE) of 'Ota Industrial Housing Estate' in Ota, Ogun State, Nigeria

Similarly, illustrated in Figure 4 are the varying concentrations of four (4) selected heavy-metals $\left[\operatorname{Iron}\left(F e^{3+}\right), \mathrm{Lead}\left(P b^{2+}\right)\right.$, Zinc $\left(\mathrm{Zn}^{2+}\right)$ and Chromium $\left(\mathrm{Cr}^{2+}\right)$ detected in the soils of the Control-environment and the four (4) Catchments that comprised the study-area. The Iron $\left(\mathrm{Fe}^{3+}\right)$ soil concentrations recorded within the study-area ranged from $370.19 \mathrm{mg} / \mathrm{Kg}(\mathrm{Catchment}$ 4) to $433.68 \mathrm{mg} / \mathrm{Kg}$ (Catchment 3) and averaged at $396.94 \mathrm{mg} / \mathrm{Kg}$, while an Iron concentration of $409.43 \mathrm{mg} / \mathrm{Kg}$ was recorded at the Control-environment's soil.

\section{Chart of Soil Heavy metals' Concentration obtained during the Post-Project}

Environmental Impact Evaluation (EIE) of 'Ota Industrial Housing Estate' in Ota, Ogun State, Nigeria

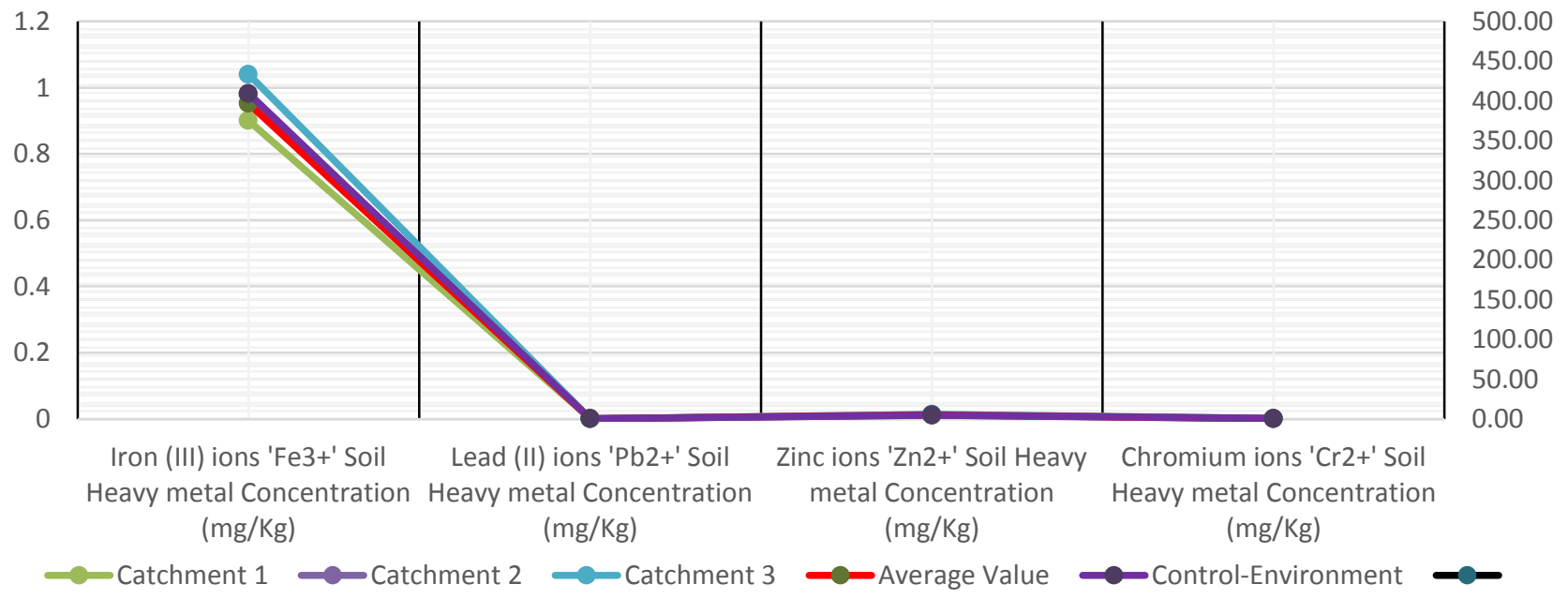

Figure 4: Chart of soil Heavy Metals' Concentrations obtained during the Post-Project Environmental Evaluation (EIE) of 'Ota Industrial Housing Estate' in Ota, Ogun State, Nigeria 
The Lead $\left(\mathrm{Pb}^{2+}\right)$ soil concentrations recorded within the study-area ranged from $0.37 \mathrm{mg} / \mathrm{Kg}$ (Catchment 4$)$ to $0.43 \mathrm{mg} / \mathrm{Kg}$ (Catchment 2) and averaged at $0.40 \mathrm{mg} / \mathrm{Kg}$ - the exact same concentration recorded at 'Catchment 1', while a Lead concentration of $0.42 \mathrm{mg} / \mathrm{Kg}$ was recorded at the Control-environment's soil.

The Zinc $\left(\mathrm{Zn}^{2+}\right)$ soil concentrations recorded within the study-area ranged from $4.25 \mathrm{mg} / \mathrm{Kg}$ (Catchment 4$)$ to $5.79 \mathrm{mg} / \mathrm{Kg}$ (Catchment 3) and averaged at 5.14mg / $\mathrm{Kg}$, while a Zinc concentration of $4.88 \mathrm{mg} / \mathrm{Kg}$ was recorded at the Control-environment.

The Chromium $\left(\mathrm{Cr}^{2+}\right)$ soil concentrations recorded within the study-area ranged from $0.51 \mathrm{mg} / \mathrm{Kg}$ (Catchment 2) to $0.66 \mathrm{mg} / \mathrm{Kg}$ (Catchment 3) and averaged at $0.59 \mathrm{mg} / \mathrm{Kg}$-slightly less than the Chromium concentration at 'Catchment 4', while a chromium concentration of $0.65 \mathrm{mg} / \mathrm{Kg}$ was recorded at the Control-environment.

Thus, from the above soil study results, it is clear that, the soil nutrient and heavy metal specie(s) and concentrations of each Catchment each Catchment does not necessarily depend on the distance of a catchment from the industrial wing of the estate, but rather on the unique chemical nature of the catchment's soil, and the localized leachate(s) and underground seepages of improperly disposed waste products associated with the industrial activities of the locally sited company(ies) in a particular catchment.

Also, as is illustrated in Figure 5, the land use types and the corresponding spread percentages are summarily discussed as follows: the predominant land use type within the study-area id 'Residential (Housing)' which is estimated to be 62\%, while the least is 'School (Educational facility)' estimated to be $1 \%$. Now, in between both extremes are 'Religious/worship centers' [i.e. churches \& mosques] $\square 2 \%$, 'Farming' [i.e. temporary subsistence/peasant farm lands] $\square 10 \%$, Non-manufacturing business ventures $\square 5 \%$ and presently 'Unused lands' $\square 20 \%$.

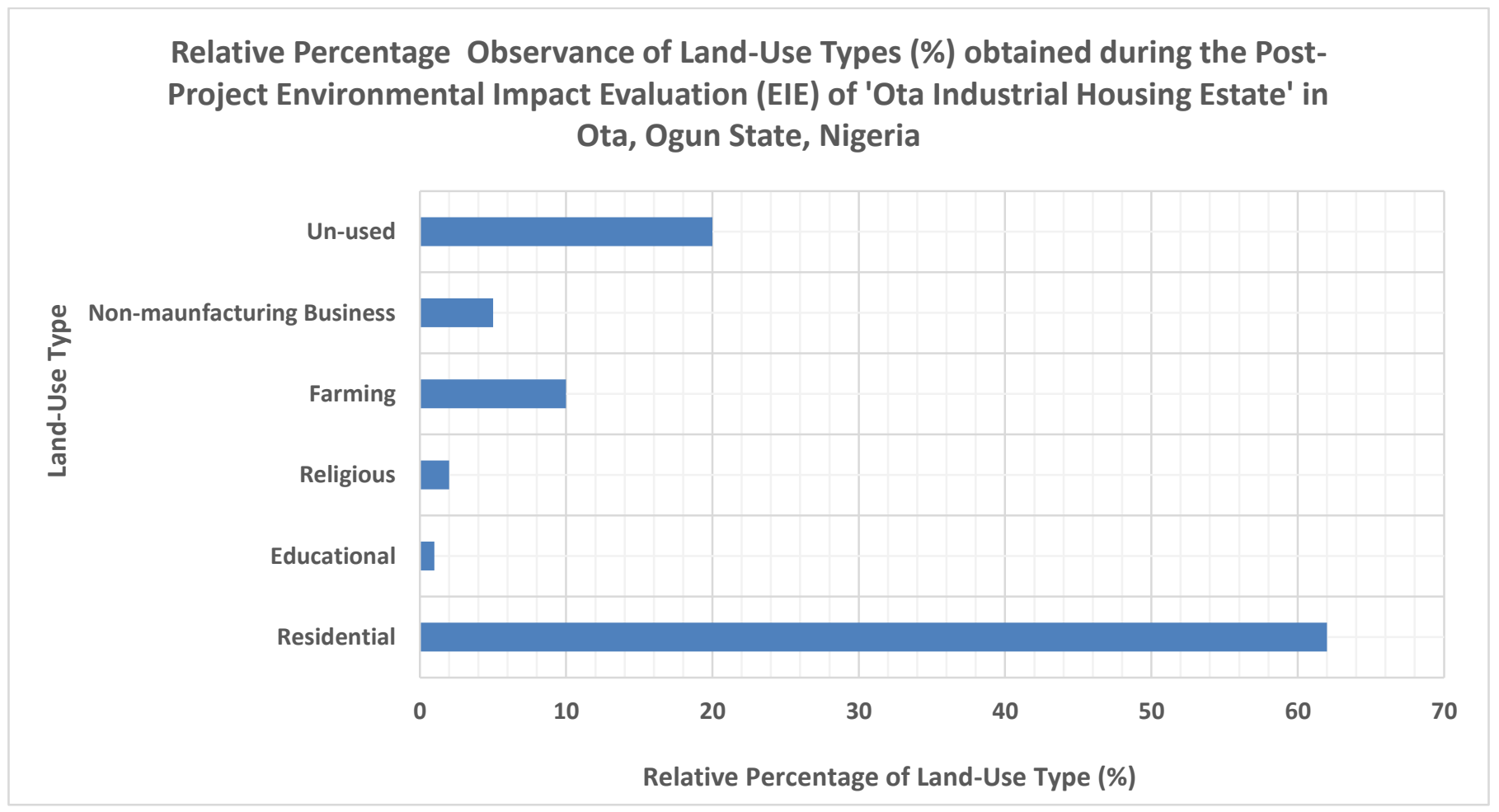

Figure 5: Chart of Relative Percentage Observance of Land-Use Types obtained during the Post-Project Environmental Evaluation (EIE) of 'Ota Industrial Housing Estate' in Ota, Ogun State, Nigeria

In the Control-environment and the four (4) catchments that comprised the study-area, four (4) selected groups of vegetation [i.e. Weeds, Edible herbs, Shrubs and Trees] were identified, as illustrated in Figure 6. First and foremost, within the weed vegetative group, the predominant weed was the 'Elephant grass' (Botanical name: 'Permisetum Purpuretum') — which was observed to be 
present at 69\% [in Catchment 1], 75\% [in Catchment 2], 81\% [in Catchment 3], 87\% [in Catchment 4] and [in the Controlenvironment]. It was then followed by another weed i.e. the 'African feather grass' (Botanical name: 'Cenchrus Macrourus') with presence (occurring) percentages of: $30 \%, 20 \%, 16 \%, 13 \%$ and 4\% in Catchments 1-4 and the Control-environment respectively. Also, the least present weed was the 'Carpet grass' (Botanical name: 'Anoxopus Compressus') occurring at percentages of: $1 \%$ (Catchment 1) $5 \%$ (Catchment 2), 3\% (Catchment 3), 0\% (Catchment 4) and 0\% (Controlenvironment).

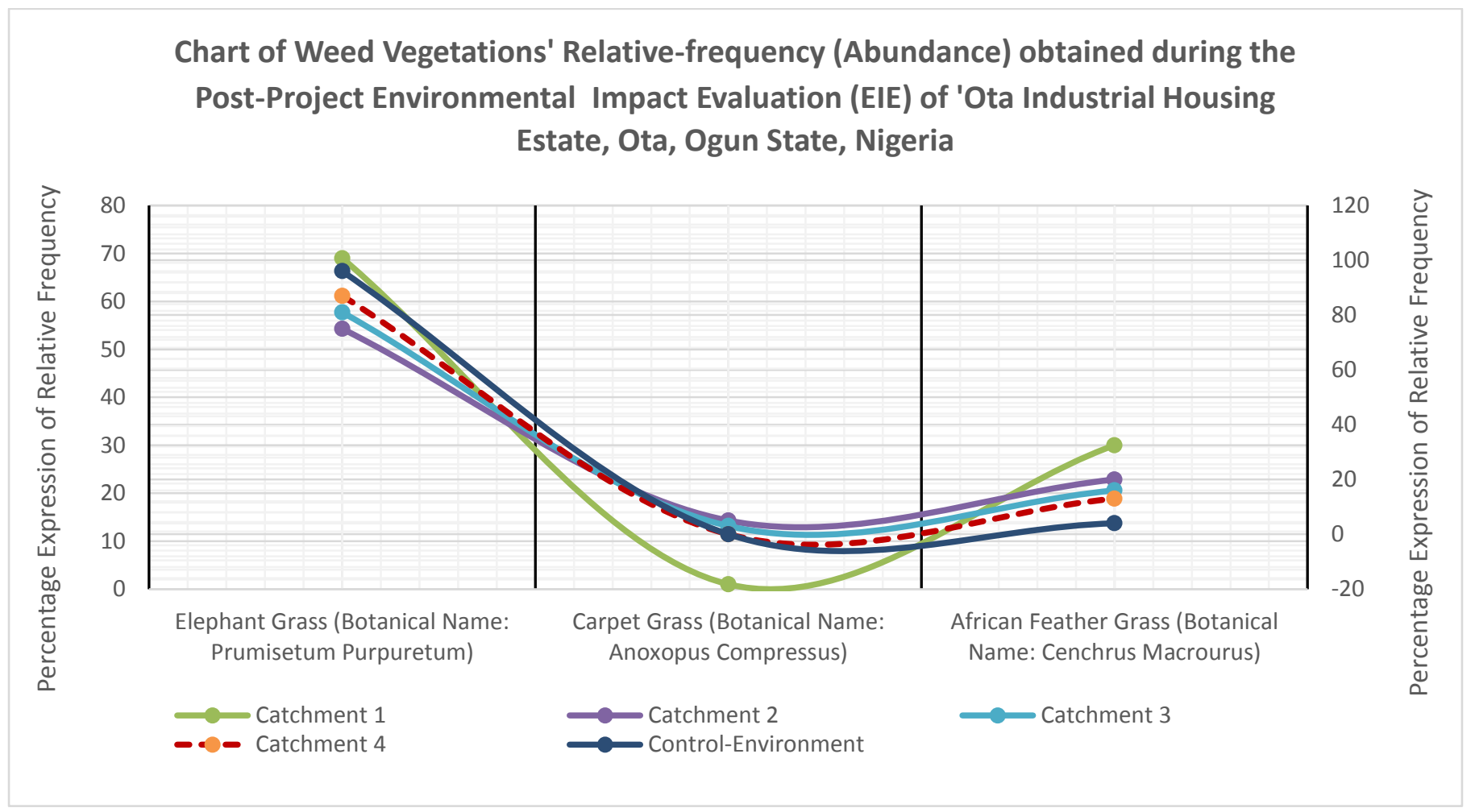

Figure 6: Chart of Weed vegetations' Relative Frequency obtained during the Post-Project Environmental Evaluation (EIE) of 'Ota Industrial Housing Estate' in Ota, Ogun State, Nigeria

Now, it is important to notice that, in order to effectively discuss the results of the relative population (availability/occurrence) assessments of the weeds, edible herbs, shrubs and trees selected for this study, and which are graphically illustrated with charts in Figure 7, Figure 8 and Figure 9, a 'Numerical Expression of Relative Frequency' was assigned to each particular selected weed, edible herb and tree found to be present or absent in the four Catchments and the Control-environment, as summarily contained in Table 1.

Table 1. Numerical-Expressions (Numbers) of Relative Frequency assigned to different the Vegetations dependent on the condition of their 'Absence' or 'Presence' in the four Catchments of the Study-area.

\begin{tabular}{|c|c|}
\hline Condition of Absence or Presence in a Catchment & Numerical Expression of Relative Frequency \\
\hline 'Absent' & 1 \\
\hline 'Almost Absent' & 2 \\
\hline 'Scarcely Present' & 3 \\
\hline 'Present' & 4 \\
\hline 'Commonly Present' & 5 \\
\hline 'Abundantly Present' & \\
\hline
\end{tabular}

Secondly, within the Edible herb vegetative group, 'Bitter leaf plant' (Botanical name: 'Vernonia Amygdalina') was found to be 'Absent' in both Catchment 1 and Catchment 3, but 'Present' in Catchment 2, 'Commonly-presently' in Catchment 4 and 
'Abundantly-present' in Control-environment. The other edible herb identified i.e. 'Water leaf plant' (Botanical name: 'Talinum Fruitcosum') was found to be 'Absent' in both Catchment 1 and Catchment 2, but 'Almost-absent' in Catchment 3, and 'Scarcelypresent' in both Catchment 4 and Control-environment.

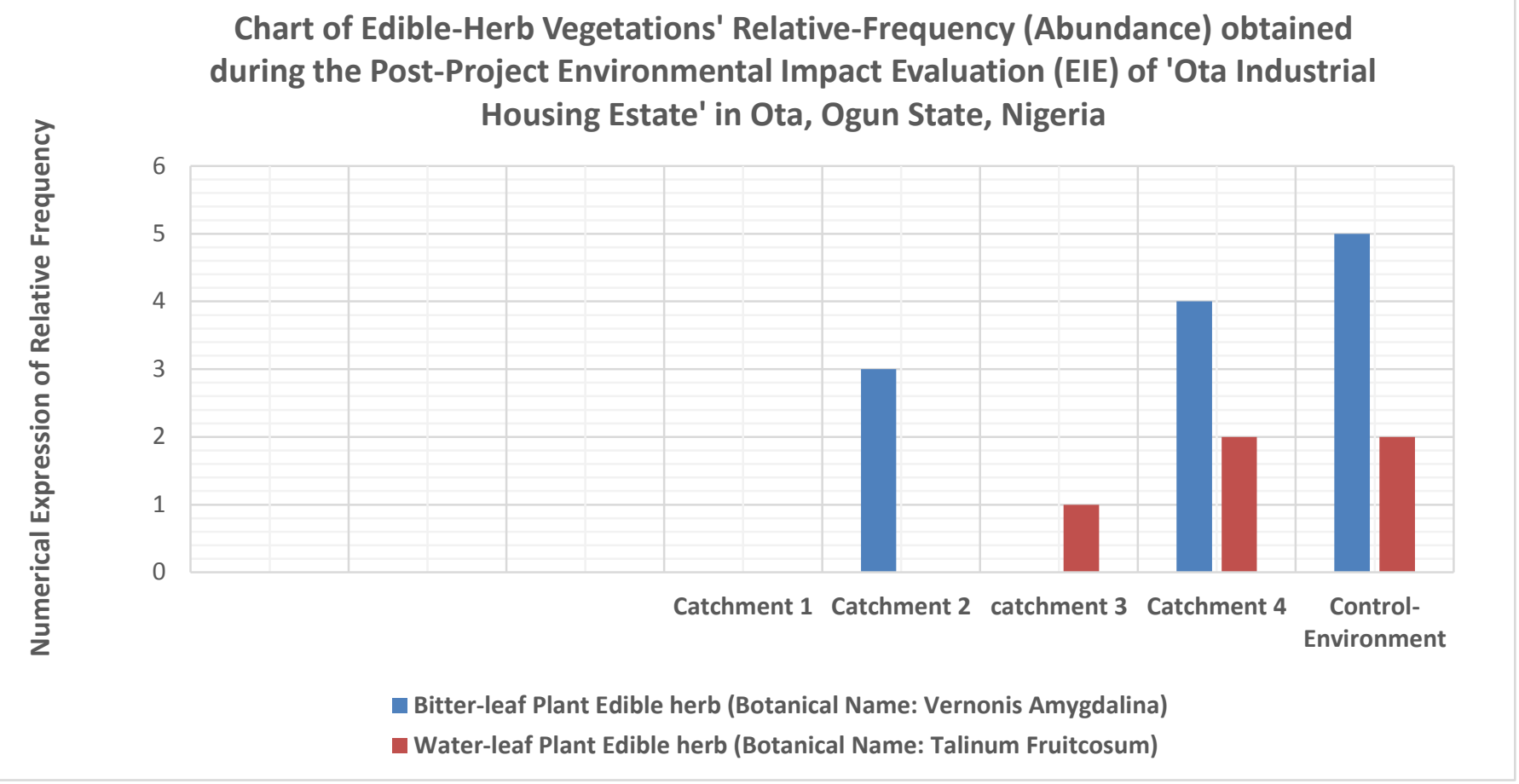

Figure 7: Chart of Edible-herb Vegetation Relative Frequency obtained during the Post-Project Environmental Evaluation (EIE) of 'Ota Industrial Housing Estate' in Ota, Ogun State, Nigeria

Then, within the $0.5-4.0 \mathrm{~m}$ high shrub vegetative group, 'Terminalia umbrella tree' (Botanical name: 'Terminalia Mantaly') was found to be 'absent' in Catchment 3, but 'Almost-absent' in both Catchment 1 and Control-environment, 'Scarcely-present in Catchment 2 and 'Present' in Catchment 4. On the other hand, 'Croton tree' (Botanical name: 'Cordiaeum Variegatum') was found to be 'Almost-absent' in Catchment 2, Catchment 4 and Control-environment, 'Scarcely-present' in Catchment 3 and 'Present' in Catchment 1.

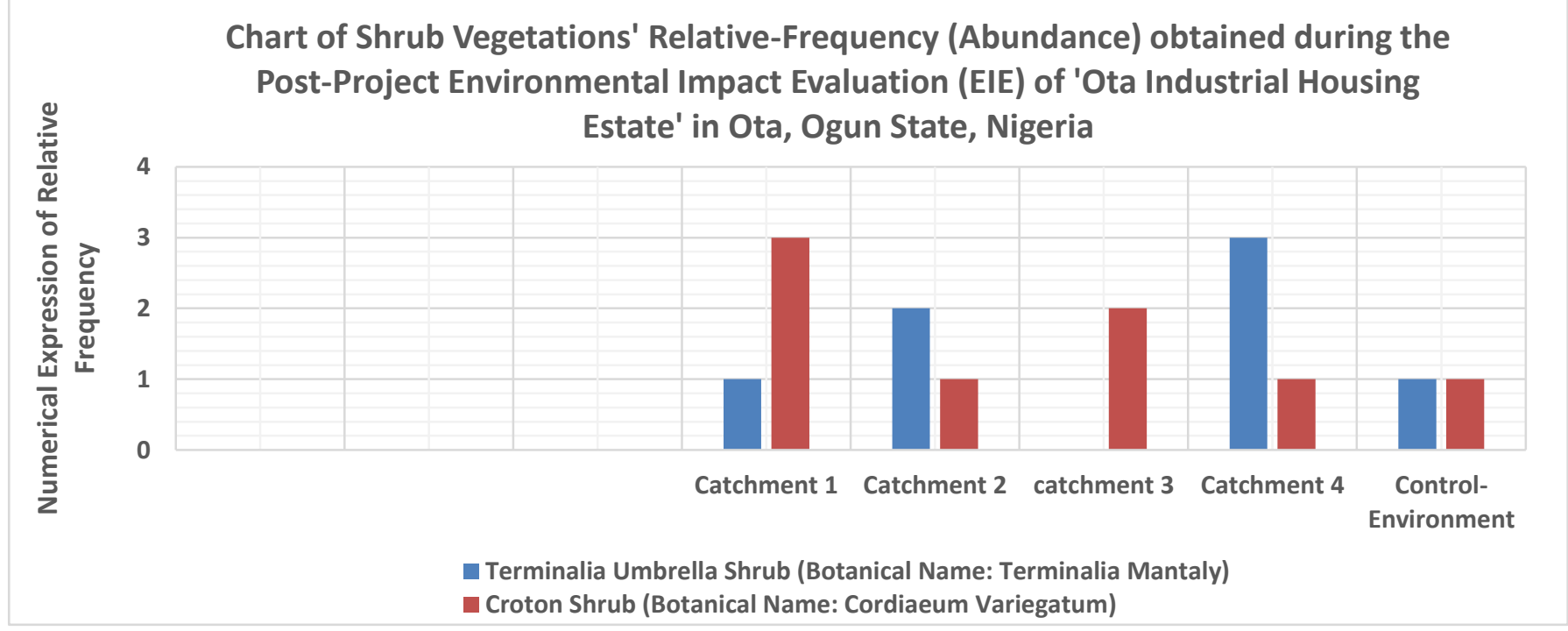

Figure 8: Chart of Shrub Vegetations' Relative Frequency obtained during the Post-Project Environmental Evaluation (EIE) of 'Ota Industrial Housing Estate' in Ota, Ogun State, Nigeria

After which, a careful consideration of the over $4.0 \mathrm{~m}$ high tree vegetative group revealed that : 'Cabbage Tree' (Botanical name: 'Cordyline Fruitcosa') was found to be 'Almost-absent' in both Catchment 2 and Catchment 4, 'Present' in Catchment 3, and 
'Scarcely-present' in both Catchment 1 and Control-environment. Also, 'Bamboo tree' (Botanical name: 'Bambusa Vulgaris') was found to be 'Present' in Control-environment, 'Scarcely-present' in Catchment 4, 'Commonly-present' in both Catchment 1 and Catchment 3, and 'Abundantly-present' in Catchment 2.

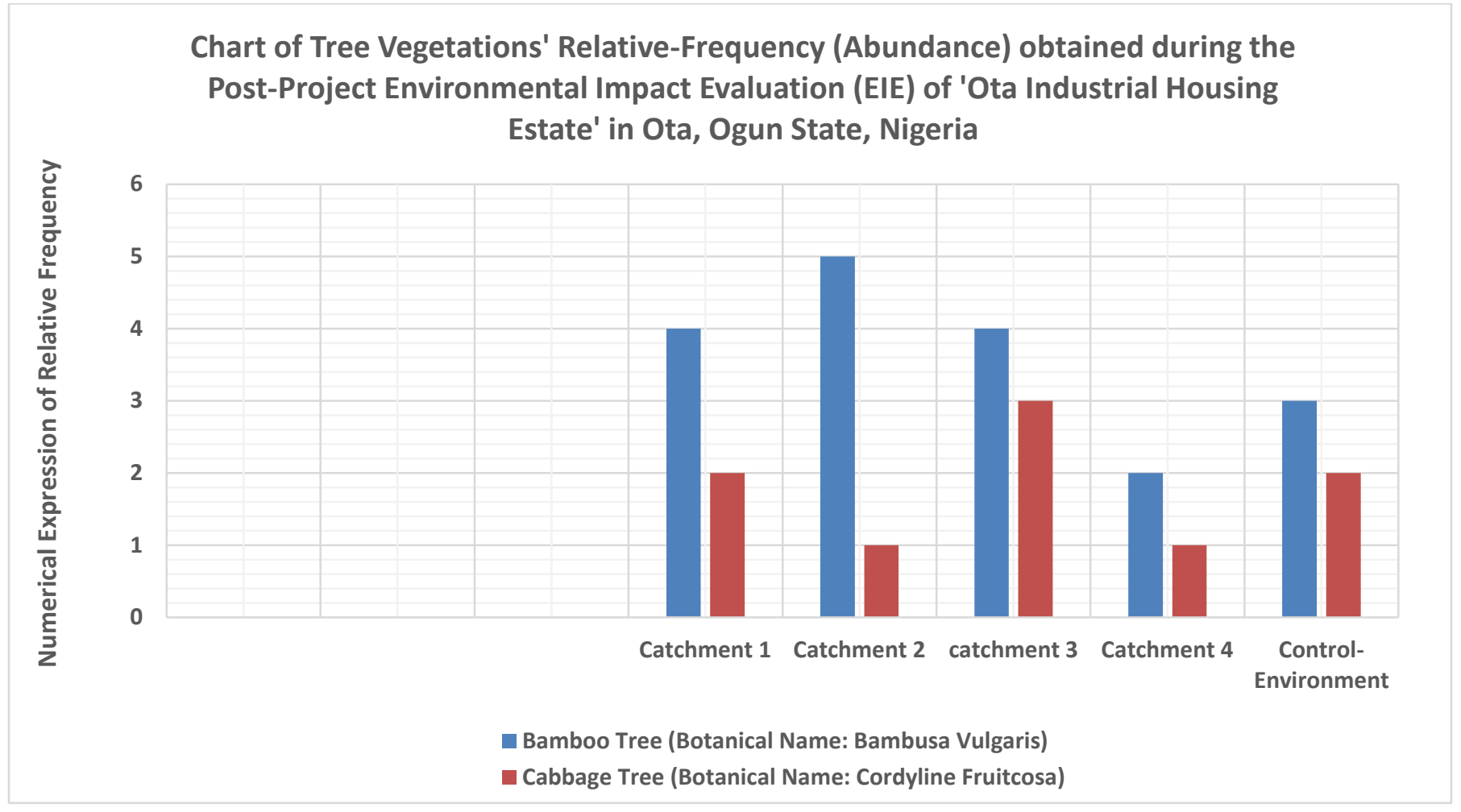

Figure 9: Chart of Tree Vegetation Relative Frequency obtained during the Post-Project Environmental Evaluation (EIE) of 'Ota Industrial Housing Estate' in Ota, Ogun State, Nigeria

The results of the physio-chemical analyses of the groundwater samples [with temperature values of $29.43^{\circ} \mathrm{C}, 30.22^{\circ} \mathrm{C}$, $30.07^{\circ} \mathrm{C}$ and $28.95^{\circ} \mathrm{C}$ ] collected (fetched) from boreholes sank in Catchments $1,2,3$ and 4 respectively [within the studyarea] and the Control-environment $\left(29.61^{\circ} \mathrm{C}\right.$ ) [which is about $15 \mathrm{Km}(15000 \mathrm{~m})$ from the study-area] are graphically illustrated in Figure 10 and summarily discussed below.

Figure 10 shows that, the groundwater $p H$ [which is simply the negatively logarithm to base 10 of the hydrogen-ion concentration in the groundwater samples] ranged from 4.3 [at Catchment 1] to 5.1 [at Catchment 4] and averaged at 4.9indicating acidity and were below that of the $W H O$ recommended potable (safe drinking) water $p H$ range of $6.5-8.5$ and the Control-environment's groundwater $p H$ value of 6.9 - which lies within the $W H O$ recommended $p H$ range and is very close to the $p H$ value of neutral water which is 7.0 .

Also from Figure 10, it was observed that, the groundwater alkalinity [which is a measure of the groundwater sample's hydroxylion (radical) concentration] ranged from $17.00 \mathrm{mg} / \mathrm{L}$ [at Catchment 4] to $22.00 \mathrm{mg} / \mathrm{L}$ [at Catchment 1] and averaged at $19.00 \mathrm{mg} / \mathrm{L}$ — exactly the very same value measured at Catchment 2] - these values are lower than the $W H O$ recommended potable water maximum alkalinity of $120.00 \mathrm{mg} / \mathrm{L}$, but are higher than the Control-environment's groundwater alkalinity value of $1.21 \mathrm{mg} / \mathrm{L}$.

Similarly, Figure 10 shows that, the groundwater salinity [which is a measure of the saltiness of the groundwater] ranged from $22.00 \mathrm{mg} / \mathrm{L}$ [at Catchment 2] to $31.00 \mathrm{mg} / \mathrm{L}$ [at catchment 1] and averaged at $26.00 \mathrm{mg} / \mathrm{L}$-these values are lower than the WHO recommended potable water maximum Salinity limit of $200.8 \mathrm{~g}$, but are higher than the Controlenvironment's groundwater Salinity level of $20.00 \mathrm{mg} / \mathrm{L}$. 
Chart of Groundwater Physio-chemical Analyses Results obtained during the

Post-Project Environmental Impact Evaluation (EIE) of 'Ota Industrial Housing Estate' in Ota, Ogun State, Nigeria

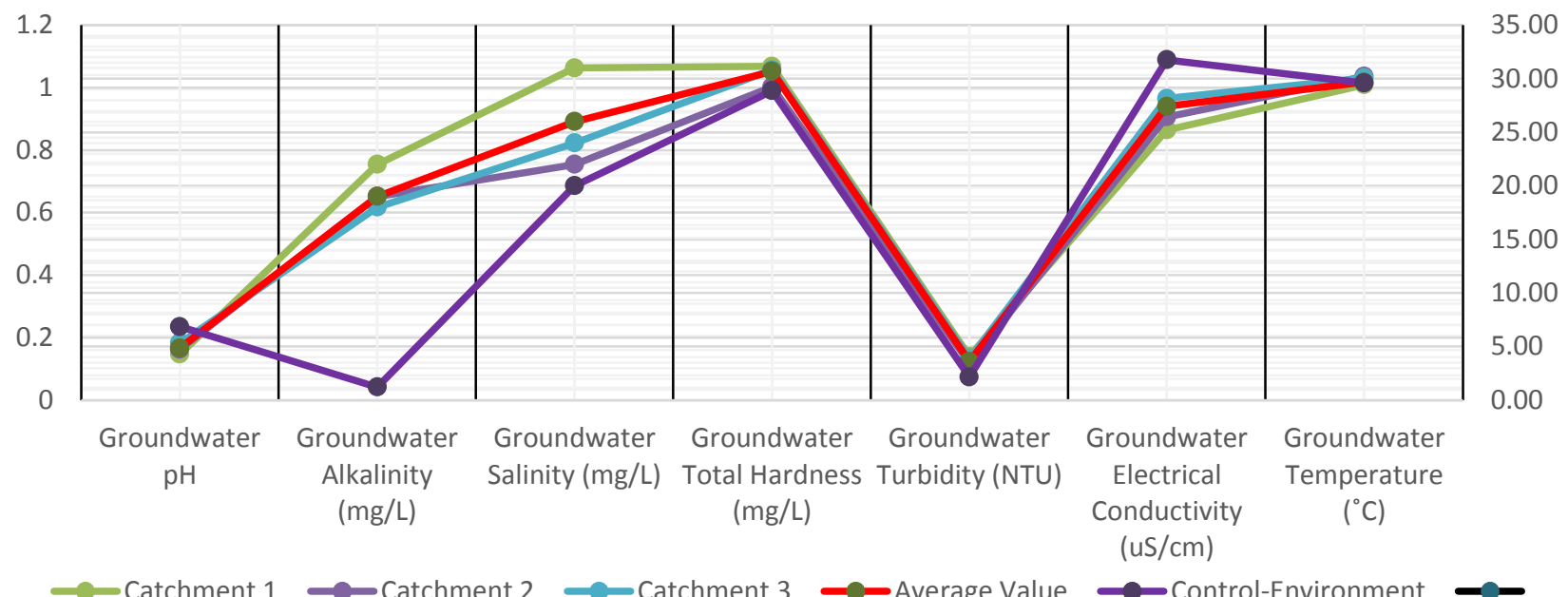

Figure 10: Chart of Groundwater Physio-chemical Analyses Results obtained during the Post-Project Environmental Evaluation (EIE) of 'Ota Industrial Housing Estate' in Ota, Ogun State, Nigeria

Again, Figure 10 shows that, the groundwater Total hardness [which oftentimes is a measure of the Calcium and Magnesium ions present in the groundwater samples in the form of 'trioxocarbonates (V)' ranged from 29.24mg / L 29.24mg/L [in Catchment 2] to $31.57 \mathrm{mg} / \mathrm{L}$ [in Catchment 4] and averaged at $30.70 \mathrm{mg} / \mathrm{L}$ [slightly below the value of $30.83 \mathrm{mg} / \mathrm{L}$ measured at Catchment 3] - these values are lesser than the Standards Organization of Nigeria's (SON) recommended potable water maximum Total hardness limit of $150.00 \mathrm{mg} / \mathrm{L}$, but are higher than the Control-environments' groundwater's Total hardness values of $28.88 \mathrm{mg} / \mathrm{L} 28.88 \mathrm{mg} / \mathrm{L}$.

Also Figure 10 shows that, the groundwater Turbidity [which is a measure of the clearness or cloudiness of the groundwater] ranged from 2.99NTU [at Catchment 4] to 4.08NTU [at Catchment 1] and averaged at 3.06NTU — these values which are lesser than the WHO recommended potable water maximum turbidity limit of 5.00NTU, and lesser than the Controlenvironment's groundwater's turbidity value of $2.16 \mathrm{NTU}$.

More so, Figure 10 shows that, the Electrical-conductivity [which is a measure of the groundwater's ability to transmit electricity as a result of the various ionic species present] ranged from $25.21 \mu \mathrm{S} / \mathrm{cm}$ [at Catchment 1] to $29.86 \mu \mathrm{S} / \mathrm{cm}$ [at Catchment 4], and averaged at $27.42 \mu \mathrm{S} / \mathrm{cm}$ - these values which are lower than the $W H O$ recommended potable water maximum Electrical-conductivity limit of $400.00 \mu \mathrm{S} / \mathrm{cm}$, and also lesser than the Control-environment's groundwater Electricalconductivity value of $31.77 \mu \mathrm{S} / \mathrm{cm}$.

Also, as could be seen from Figure 11, the results of the mineral content analyses of the groundwater samples sourced from boreholes in the Control-environment and the four Catchments in the study-area are thus presented. Thus, while the Catchment's Exchangeable Cations' concentration ranges and average values were: 9.25-45.62mg/ L 24.27 $\mathrm{mg}^{\mathrm{L}} \mathrm{L}\left(\mathrm{Na} \mathrm{a}^{+}\right)$; 3.27-6.94mg/L , 5.09mg/L $\left(K^{+}\right) ; 47.39-74.25 m g / L, 60.85 m g / L\left(\mathrm{Ca}^{2+}\right)$ and 26.08-32.80mg/L , 29.22mg/ $\mathrm{L}\left(\mathrm{Mg}^{2+}\right)$ respectively; the ranges and average values of the Chlorides, Sulphates and Nitrates were: 84.20-136.58mg/L, 107.44mg/L $\left(\mathrm{Cl}^{-}\right) ; 4.88-5.39 \mathrm{mg} / \mathrm{L}, \quad 5.06 \mathrm{mg} / \mathrm{L}\left(\mathrm{SO}_{4}^{2-}\right)$ and $2.30-3.33 \mathrm{mg} / \mathrm{L}$, $2.09 \mathrm{mg} / \mathrm{L}\left(\mathrm{NO}_{3}^{2-}\right)$ respectively. Thus, it is important to note that the above concentrations are all below the applicable

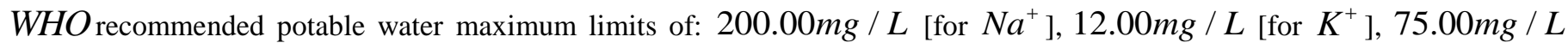
[for $\mathrm{Ca}^{2+}$ ], $150.00 \mathrm{mg} / \mathrm{L}$ [for $\mathrm{Mg}^{2+}$ ], 250.00mg / L [for $\mathrm{Cl}^{-}$], 250.00mg / L [for $\mathrm{SO}_{4}^{2-}$ ], and $50.00 \mathrm{mg} / \mathrm{L}$ [for 
$\mathrm{NO}_{3}^{2-}$ ]; but are higher than the Control-environment's respective values of: $5.13 \mathrm{mg} / \mathrm{L}\left(\mathrm{Na}^{+}\right), 2.20 \mathrm{mg} / \mathrm{L}^{+}\left(\mathrm{K}^{+}\right)$, $36.12 \mathrm{mg} / \mathrm{L}\left(\mathrm{Ca}^{2+}\right), 25.25 \mathrm{mg} / \mathrm{L}\left(\mathrm{Mg}^{2+}\right), 76.51 \mathrm{mg} / \mathrm{L}\left(\mathrm{Cl}^{-}\right), 3.73 \mathrm{mg} / \mathrm{L}\left(\mathrm{SO}_{4}^{2-}\right)$ and $1.84 \mathrm{mg} / \mathrm{L}^{-}\left(\mathrm{NO}_{3}^{-}\right)$.

\section{Chart of Groundwater Mineral Content Analyses Results obtained during the Post- Project Environmental Impact Evaluation (EIE) of 'Ota Industrial Housing Estate' in Ota, Ogun State, Nigeria}

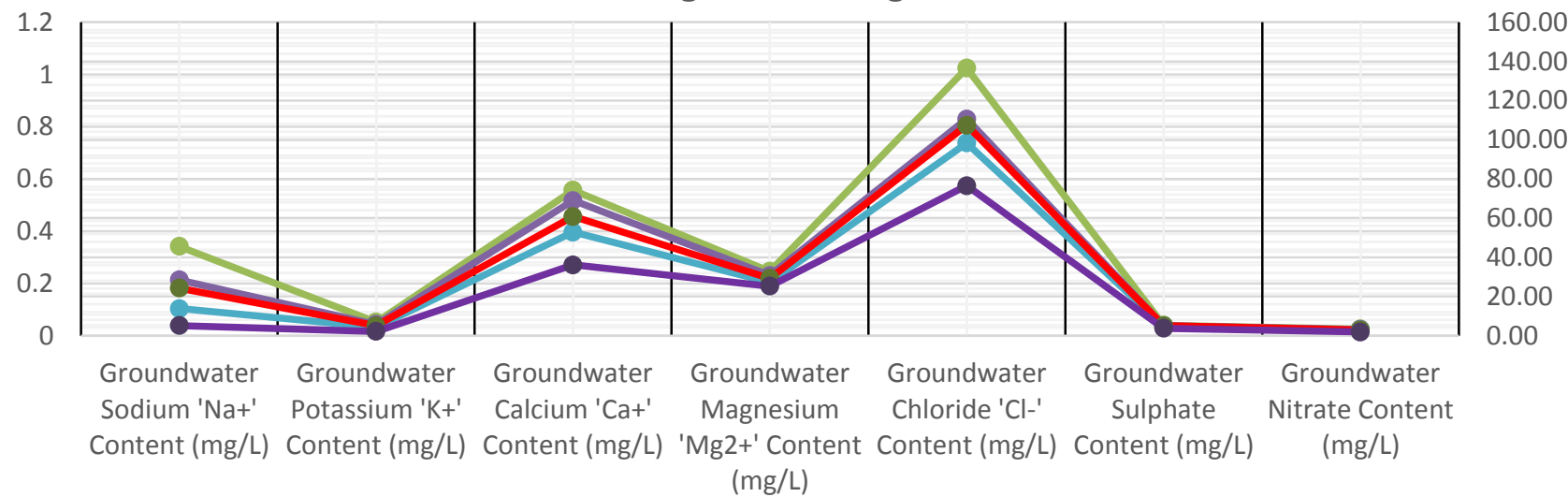

-Catchment $1-$ Catchment $2-$ Catchment $3 \longrightarrow$ Average Value $\longrightarrow$ Control-Environment

Figure 11: Chart of Groundwater Mineral Content Analyses Results obtained during the Post-Project Environmental Evaluation (EIE) of 'Ota Industrial Housing Estate' in Ota, Ogun State, Nigeria

'Total Solids $(T S)$ ' is defined as the entire mass of the material residue remnant in vessel after the evaporation of a groundwater sample, accompanied by a second process of oven-heating to drying at a specified temperature. Also, it is the sum of 'Total Dissolved Solids $(T D S)$ ' and 'Total Suspended Solids $(T S S)$ '. Now, based on the results of the solubility and $B O D$ analyses of the groundwater samples [sourced from boreholes in the Control-environment and the Study-area's Catchments] as illustrated in Figure 12, the understated should be noted. The TS ranged from $38.95 \mathrm{mg} / \mathrm{L}$ to $56.34 \mathrm{mg} / \mathrm{L}$ with an average value of 48.01 $\mathrm{mg} / \mathrm{L}$, while the TDS and TSS ranged from 32.12-52.91 $\mathrm{mg} / \mathrm{L}$ and $1.83-3.43 \mathrm{mg} / \mathrm{L}$ respectively, and had average values of $45.53 \mathrm{mg} / \mathrm{L}$ and $2.48 \mathrm{mg} / \mathrm{L}$ respectively. Thus, it is obvious that thee above range and average value of $T D S$ are far lesser than the $W H O$ recommended potable water maximum Total Dissolved Solis value of $600.00 \mathrm{mg} / \mathrm{L}$ and that, two catchments had TDS values which were greater than the Control-environment's $T D S$ value of $2.48 \mathrm{mg} / \mathrm{L}$.

Chart of Groundwater 'Total Dissolved Solids', 'Total Suspended Solids', 'Total Solids','Dissolved Oxygen' and 'Biochemical Oxygen Demand' Analyses Results obtained during the Post-Project Environmental Impact Evaluation (EIE) of 'Ota Industrial Housing $E$

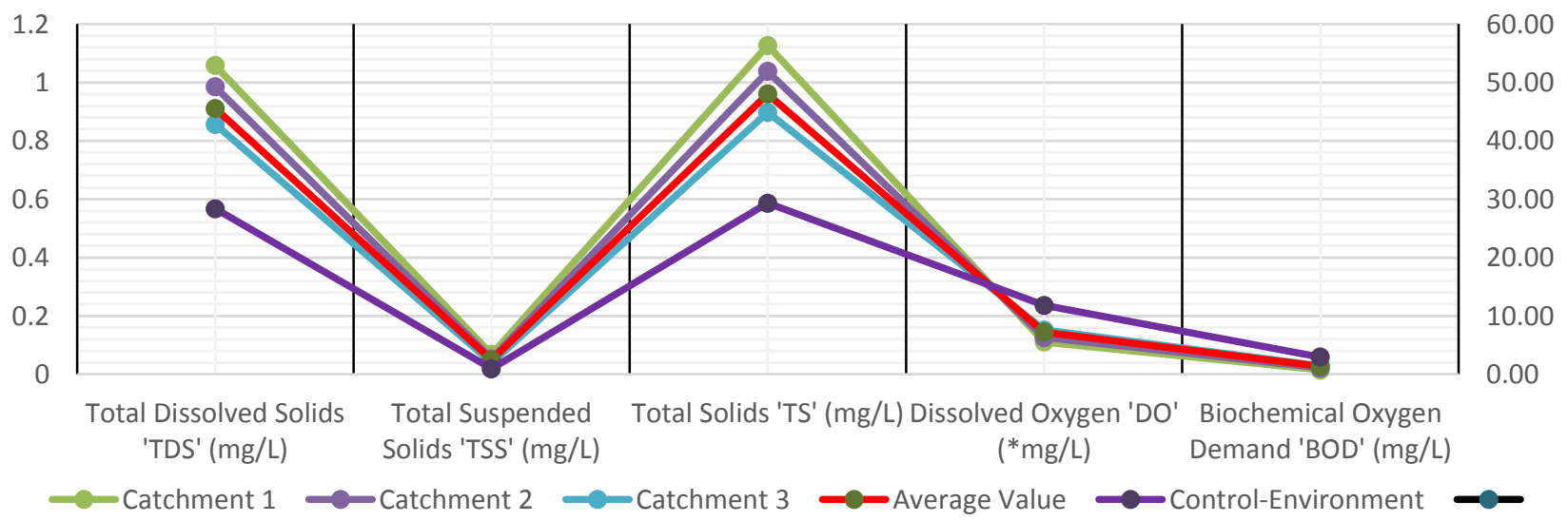

Figure 12: Chart of Groundwater TDS, TSS, TS, DO and BOD Analyses Results obtained during the Post-Project Environmental Evaluation (EIE) of 'Ota Industrial Housing Estate' in Ota, Ogun State, Nigeria 
In addition, the chart in Figure 13, graphically illustrates the results of the heavy-metal content analyses of the groundwater samples-which is summarily discussed below. The Lead $\left(\mathrm{Pb}^{2+}\right)$ concentrations ranged from $0.063 \mathrm{mg} / \mathrm{L}$ [at Catchment 4] to $0.087 \mathrm{mg} / \mathrm{L}$ [at Catchment 1] an averaged at $0.074 \mathrm{mg} / \mathrm{L}$ - [exactly the same value as was measured at Catchment 2]these values are higher than the WHO recommended potable water maximum Lead limit of $0.010 \mathrm{mg} / \mathrm{L}$ — this could result in cancer and nervous system dysfunction for the human consumers of water samples in these Catchments, while it must be noted that, no lead was found to be present in the Control-environment's underground water sample.

\section{Chart of Groundwater Heavy metal Content Analyses Results obtained during the Post-Project Environmental Impact Evaluation (EIE) of 'Ota Industrial Housing Estate' in Ota, Ogun State, Nigeria}

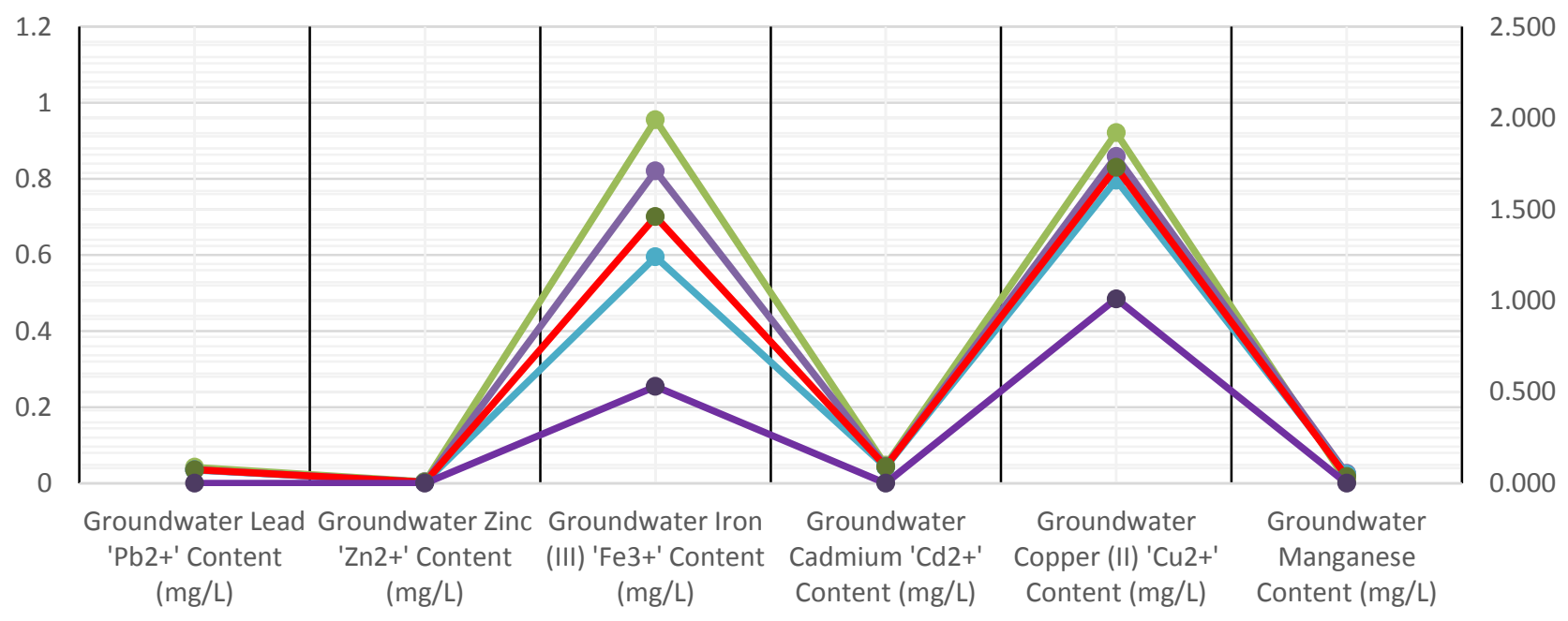

-Catchment $1-$ Catchment $2-$ Catchment $3-$ Average Value $\longrightarrow$ Control-Environment $\longrightarrow$

\section{Figure 13: Chart of Groundwater Heavy Metals Content Analyses Results obtained during the Post-Project Environmental Evaluation (EIE) of 'Ota Industrial Housing Estate' in Ota, Ogun State, Nigeria}

The Zinc $\left(\mathrm{Zn}^{2+}\right)$ concentrations ranged from $0.005 m g / L$ [at Catchment 3] to $0.008 m g / L$ [at Catchment 1] an averaged at $0.005 \mathrm{mg} / \mathrm{L}$ - [which was the exact same value obtained at Catchment 2] - Now, these values are lower than the WHO recommended potable water maximum Zinc limit of 5.000 $\mathrm{mg} / \mathrm{L}$, while no Zinc was found to be present in both 'Catchment 4' and the Control-environment's groundwater samples.

The Iron $\left(\mathrm{Fe}^{3+}\right)$ concentrations ranged from $0.88 \mathrm{mg} / \mathrm{L} 0.88 m g / L$ [at Catchment4] to $1.99 m g / L$ [at Catchment 1 ] and averaged at $1.46 \mathrm{mg} / \mathrm{L}$ - these values are much higher than the $\mathrm{WHO}$ recommended potable water maximum Iron limit of $0.100 \mathrm{mg} / \mathrm{L}$ and also higher than the Control-environment's groundwater Iron content of $0.053 \mathrm{mg} / \mathrm{L}$. At the moment, excessive Iron content in water has not been traced to any ill-health condition in humans.

The Cadmium $\left(\mathrm{Cd}^{2+}\right)$ concentrations ranged from 0.083mg / L [at Catchment 4] to 0.098mg / L [at Catchment 1] and averaged at $0.091 \mathrm{mg} / \mathrm{L}$. These values are higher than the WHO recommended potable water maximum Cadmium limit of $0.003 \mathrm{mg} / \mathrm{L}$ - this may result in kidney-related ill-health conditions in man, while it should be noted that none was found present in the Control-environment's groundwater sample.

The Copper $\left(\mathrm{Cu}^{2+}\right)$ concentrations ranged from $1.530 \mathrm{mg} / \mathrm{L}$ [at Catchment 4] to $1.920 \mathrm{mg} / \mathrm{L}$ [at Catchment 1] and averaged at $1.730 \mathrm{mg} / \mathrm{L}$. These values are higher than the United States Environmental Protection Agency (USEPA) recommended potable water maximum Copper limit of $1.300 \mathrm{mg} / \mathrm{L}$ [45] and also higher than the Control-environment's 
groundwater copper concentration of $1.010 \mathrm{mg} / \mathrm{L}$. This would most likely result in diarrhoea, headache, vomiting, stomach disorders and feeling of nausea etc.

The Manganese $\left(\mathrm{Mn}^{2+}\right)$ concentrations ranged from $0.041 \mathrm{mg} / \mathrm{L}$ [at Catchment 3] to 0.053mg / L [at Catchment1] and averaged at $0.036 \mathrm{mg} / \mathrm{L}$. These values are lower than the WHO recommended potable water maximum Manganese limit of $0.100 \mathrm{mg} / \mathrm{L}$, while none was found to be present in the underground water sourced (fetched) from boreholes sank in both 'Catchment 4' and the 'Control-environment'.

\section{Chart of Groundwater Microbial Analyses Results obtained during the Post-Project Environmental Impact Evaluation (EIE) of 'Ota Industrial Housing Estate' in Ota, Ogun State, Nigeria}

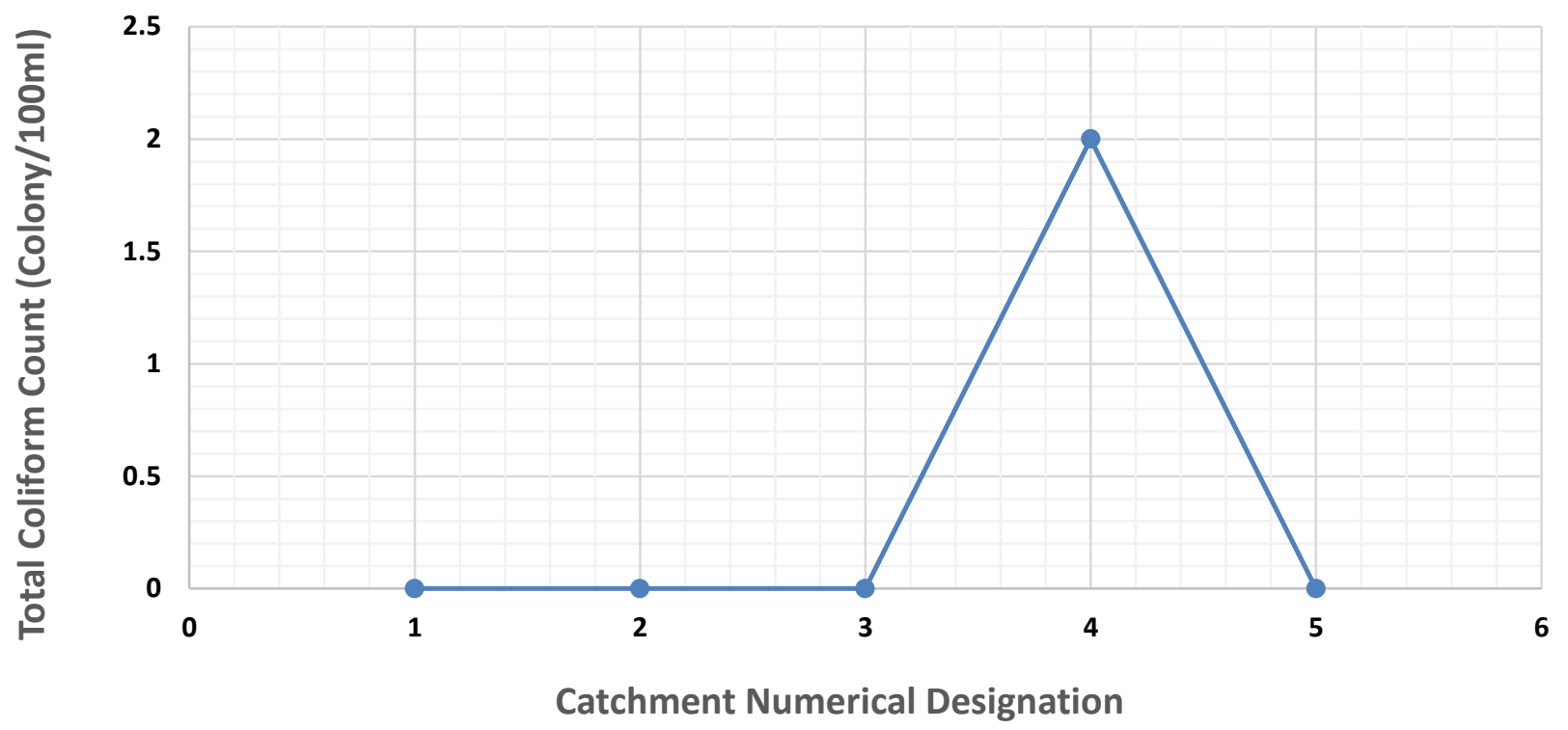

Figure 14: Chart of Groundwater Microbial Test Results obtained during the Post-Project Environmental Evaluation (EIE) of 'Ota Industrial Housing Estate' in Ota, Ogun State, Nigeria

Figure 14 shows the result of the microbiological analysis of the groundwater samples sourced from boreholes sank in the Control-environment and the four Catchments that comprised the Study-area. From which it was revealed that, all the collected groundwater samples were free of microbial contamination with the exception of the groundwater sample in 'Catchment 4' [i.e. "Obasanjo" which is the only Catchment geographically located outside 'Ogun State Industrial and Housing Estate' in Ota municipality, but within close proximity to it]; in which was found was a Total Coliform count of 2Colony/100mL. These maybe summarily explained below. The comparatively larger Land area $2081 \mathrm{~m}^{2}\left(22400 \mathrm{ft}^{2}\right)$ per plot of land acquired within the first three Catchments [i.e. 'Estate's Residential Wing Zone 1', 'Estate's Residential Wing Zone 2' and 'Estate's Residential Wing Zone 3'] allows for adequate spacing (distance) between 'Soak-away pits/Septic tanks' and 'Borehole aquifers'. However, the comparatively smaller Land area $7200 \mathrm{~m}^{2}\left(668 \mathrm{ft}^{2}\right)$ per plot of land acquired in 'Catchment 4' [i.e. 'Obasanjo'—which is geographically located outside the industrial \& housing estate] which may have constrained some land owners to site the Soakaway pits/Septic tanks and Borehole aquifers within very close proximity - which may have made underground seepage of contaminated waste-water from Soak-away pits/Septic tanks to Borehole aquifers a possibility—hence the occurrence of microbial contamination in some groundwater samples within 'Catchment 4'.

\section{CONCLUSION}

Selected microclimatic properties, an acoustic parameter, outdoor air quality parameters, soil-study properties, vegetation, land use patterns and groundwater assessment parameters of the study-area i.e. 'Ogun State Industrial Housing Estate in Ota and its environ' [which consists of three catchments inside the Estate and one catchment outside the estate] and a Control-environment [located far away $\approx 15 \mathrm{Km}$ from the Estate] have been studied for three months and compared with the relevant global standard limits/values and/or the values of the [unaffected] Control-environment, so as to evaluate (determine) the [direct \& indirect] 
environmental effects (impacts) of siting the Industrial wing of the Estate at varying distances from [the three Catchments that make-up] the Residential Wing of the Estate and a fourth Catchment i.e. 'Obasanjo locality' — which is a neighbouring residential community within a relatively close proximity to the Estate. Consequently, the understated observations were noted.

The prevailing wind is a North-Easterly wind which moves with a slightly higher windspeed in the Control-environment than the in the Study-area. The localized Air temperature and Relative humidity are lower at the Control-environment than at the Studyarea, and their values decrease with increasing distance from the Estate's Industrial wing. Similarly, the measured outdoor Ambient Noise levels are lower at the Control-environment than at the Study-area, decrease with increasing distance from the Estate's Industrial wing and are oftentimes higher than the 'WHO' and 'ISO 9001:1996' recommended limits for human safety.

Although, the three atmospheric pollutants' $\left[\mathrm{CO}(g), \mathrm{NO}_{2}(g)\right.$ and $\mathrm{SO}_{2}(g)$ ] levels [measured during the outdoor Air Quality analyses] are generally higher at the Study-area than at the Control-environment, yet it is only the ' $C O(g)$ ' whose higher-than-recommended levels could result in adverse health conditions in man. Also, the ' $\mathrm{NO}_{2}(g)$ ' and ' $\mathrm{SO}_{2}(g)$ ' levels are lower than the WHO safe recommended limits, and all three atmospheric pollutants decrease in their concentrations with increasing distance from the Estate's Industrial wing.

The characteristic concentration values of the four measured soil nutrients $\left[\mathrm{Na}^{+}, \mathrm{K}^{+}, \mathrm{Ca}^{2+} \& \mathrm{Mg}^{2+}\right]$ and the four measured soil heavy metals $\left[\mathrm{Fe}^{3+}, \mathrm{Pb}^{2+}, \mathrm{Zn}^{2+} \& \mathrm{Cr}^{2+}\right.$ ] did not show any particular trend of increase or decrease with respect to distance from the Estate's Industrial Wing nor with respect to the measured values at the Control-environment- thus indicating the presence of randomly distributed concentrations of these heavy metals, which may be a function of several geological and geotechnical considerations which are obviously beyond the scope of this study. The two commonly observed

The predominant Land use type in the Estate's residential wing is the 'Residential (Housing)' and the least is the 'Educational (Privately-owned Nursery, Primary \& Secondary Schools)', while others were 'Religious (Centers of worship i.e. Churches \& Mosques)', 'Agricultural (subsistence/peasant farming)', 'Non-manufacturing businesses' and 'Idle (Un-used)'.

Within the study-area, the predominantly occurring weeds are 'Elephant grass' (Botanical name: 'Permisetum Purpuretum') and 'African feather grass' (Botanical name: 'Cenchrus Macrourus'). The two edible herbs commonly observed were 'Bitter leaf plant' (Botanical name: 'Vernonia Amygdalina') and 'Water leaf plant' (Botanical name: 'Talinum Fruitcosum'). The two commonly observed 0.5-4.0m high shrubs were 'Terminalia umbrella tree' (Botanical name: 'Terminalia Mantaly') and 'Croton tree' (Botanical name: 'Cordiaeum Variegatum'). The two commonly observed were 'Cabbage Tree' (Botanical name: 'Cordyline Fruitcosa') and 'Bamboo tree' (Botanical name: 'Bambusa Vulgaris').

With the exceptions of $p H$, Electrical Conductivity, temperature, Dissolved Oxygen and Biochemical Oxygen demand; all other Groundwater Quality assessment Parameters are generally higher at the Study-area than at the Control-environment. In addition, with the exception of four heavy metals [i.e. 'Lead $\left(\mathrm{Pb}^{2+}\right)$ ', 'Iron $\left(F e^{3+}\right)$ ', 'Cadmium $\left(\mathrm{Cd}^{2+}\right)$ ' and 'Copper $\left(\mathrm{Cu}^{2+}\right)$ ' whose concentration were higher than the WHO and USEPA recommended safe limits and could result in 'Cancer \& Nervous' , 'no currently stated health concerns', 'Kidney-related health concerns', and 'Diarrhoea, Headache, Vomiting, stomach disorders \& Nauseating feelings']; all other examined groundwater quality-assessment parameters showed conformity to [i.e. are lower than the WHO and USEPA recommended safe limits. All the tested groundwater samples collected from the three Catchments within the Estate [i.e. 'Estate Residential Wing Zone 1', 'Estate Residential Wing Zone 2', and 'Estate Residential Wing Zone 3'] and the Control-environment [i.e. 'Atan Community'] are free of Microbial contamination, with the exception of the groundwater samples collected from 'Catchment 4' [i.e. 'Obasanjo Community' which is a neighboring residential community located outside the Estate] which were tested to be microbially contaminated with Total Coliform.

\section{RECOMMENDATIONS}

In order to initially mitigate the health implications of the environmental pollution and to eventually attempt to significantly curb (control) the menace of the environmental pollution itself, the following short-term palliative and long-term remedial measures are hereby recommended:

I. Companies operating within the Estate should always provide adequate Personal Protective Equipment (PPE) for their workers and visitors. 
II. Companies operating within the Estate should be forced by the government to increasingly adopt cleaner (green) technologies and operational processes/procedures.

III. Public enlightenment campaigns and sensitization workshops should be organized by the government to educate the public on the need to protect themselves and the environment from environmental pollution, and on the ways/strategies aimed at reducing those cases of pollution that cannot be outrightly eliminated.

IV. Further research on the subject-matter and the study-area is advised.

\section{ACKNOWLEDGMENT}

The authors wish to express their profound gratitude to GOD almighty for His mercy, grace and favour that was sufficient all through this research project. Furthermore, we will not fail to say a big 'Thank You' to the management and staff of: 'Hafalix Nigeria Limited, Port Harcourt, Nigeria', 'Redsav Nigeria Limited, Lagos, Nigeria', and 'Cintojon Company (Nigeria) Limited'.

\section{REFERENCES}

[1] O. Ibhadode, I. T. Tenebe, P. C. Emenike, O. S. Adesina, A. F. Okougha and F. O. Aitanke, "Assessment of Noise-levels of Generator-sets in Seven Cities of south-Southern Nigeria", African Journal of Science Technology, Innovation and Development, vol. 10, January 2018, pp.125-135. DOI: 10.1080/20421338.2017.1400711

[2] O. Ibhadode, A. Adekunle, Y. K. Abimiku, and N. M. Umeobika, "Noise-level Characterization of Portable Electric-power Generators in North-Central Nigeria", International Journal of Engineering Research and Advanced Technology, vol. 5, April 2019, pp.44-58. DOI: 10.31695/IJERAT.2019.3427

[3] O. Ibhadode, O. S. Oyedepo, A. S. Ogunro, A. Joseph, S. O. Banjo, I. I. Umanah, E. S. Apeh, and A. O. Ayoola, “An Experimental-assessment of Human Exposure-levels to Aircraft Noise-hazards in the Neighbouring-environments of four Nigerian Airports", IOP Conf. Ser.: Mater. Sci. Eng. 413 012080, vol. 413, DOI: 10.1088/1757-899X/413/1/012080

[4] O. Ibhadode, P. Ibhadode, A. F. Okougha, I. I. Umanah, F. O.Aitanke, and S. A. B. Fiyebo, "Hazards Assessment Analysis of Fossil-Fuel Generators: Holistic-Study of Human Experiences and Perceptions in South-Southern Nigeria", Journal of Sustainable Development Studies, vol. 9, September 2016, pp.153-242.

[5] O. Ibhadode, F. A. Okougha, C. O. Nwafor, and N. Essang, “An Experimental-study on Ventilation of Public Schools in Akure, Oshogbo and Ado-ekiti Cities in South-western Nigeria”, IOSR Journal of Mechanical and Civil Engineering, vol. 14, September 2017, pp.34-43. DOI: 10.9790/1684-1405013443

[6] O. Ibhadode, O. O. Ajayi, A. A. Abioye, J. Ismaila and A. A. Adekunle, “An Evaluation of Classroom-illumination: A critical Requirement for Effective Designing and Construction of Naturally-illuminated Schools in Nigeria", Progress in Industrial Ecology - An International Journal, vol. 13, September 2019, pp.342-472. DOI: 10.1504/PIE.2019.102849

[7] A. P. Eseigbe, O. Ibhadode, A. R. Ayoola and O. M. Sosanolu, "An Experimental Determination of Drinking Water Quality in Abeokuta Metropolis, South-Western Nigeria”, International Journal of Advances in Scientific and Engineering Research, vol. 4, December 2018, pp.241-256. DOI: 10.31695/IJASRE.2018.33035

[8] A. S. Ogbiye, I. T. Tenebe, P. C. Emenike, I. D. Diwa, D. O. Omole, M. Omeje, U. B. Ngene, O. K. Oyekweredike and O. Ibhadode, "Preliminary Assessment of the Current Pollution Status of River Atuwara, Nigeria, Within an Industrial Site: A Bivariate Approach", WIT Transactions on Ecology and the Environment, River Basin Management vol. 234, 2019, pp.209219.

[9] C. O. Nwafor, Y. Abimiku, O. Ibhadode, and E. J. Annune, "Experimental Evaluation of Radiological Hazards in Ceramic Tiles Used in the Jos-South Area of Plateau State, Nigeria”, International Journal of Advances in Scientific Research and Engineering, vol. 5, December 2019, pp.1-8. DOI: 10.31695/IJASRE.2019.33571

[10] S. A. Ahmeda, and M. Alib, "Partnerships for Solid Waste Management in Developing Countries: Linking Theories to Realities", Journal of Habitat International, vol. 28, September 2004, pp.467-479.

[11] P. Elliot, N. Eaton, G. Shaddick and R. Carter, "Cancer incidence near municipal solid waste incinerators in Great Britain. Part 2: histopathological and case-note review of primary liver cancer cases”, British Journal of Cancer, March 2000, vol. 82, pp.1103-1106.

[12] D. Laner, M. Crest, H. Sharff, J. W. F. Morris, and M. A. Barlaz, "A review of approaches for the long-term management of municipal solid waste landfills”, Waste Management, March 2012, vol. 32, pp.498-512.

[13] X. Qu, Z. Li, X. Xie, Y. Sui, L. Yang, and Y. Chen, "Survey of composition and generation rate of household wastes in Beijing, China", Waste Management, July 2009, vol. 29, pp.2618-2674.

[14] A. S. Ogunro, F. I. Apeh, O. C. Nwannenna, and O. Ibhadode, "Recycling of Waste Glass for Clay used in Ceramic Tile Production”, American Journal of Engineering Research, vol. 7, August 2018, pp.272-278. 
[15] S. Jibrin, E. Sule, J. Ismaila,O. Ibhadode, Y. A. Buba, I. W. Farida, and S. Emeson, "Use of Waste Plastics in Cement-based Composite for Lightweight Concrete Production", Journal of Research in engineering Technology, vol. 2, October 2017, pp.44-54.

[16] O. Ibhadode, A. A. Adekunle, S. O. Banjo, and O. D. Atakpu, "Thermophysical, Electrical and Mechanical Characterizations of Normal and Special Concretes: A Holistic-Empirical Investigation for Prequalification and Quality-Control of Concrete”, J. Phys.: Conf. Ser. 1378 (2019) 042100. DOI: 10.1088/1742-6596/1378/4/042100

[17] O. Ibhadode, T. Bello, A. E. Asuquo, F. W. Idris, F. A. Okougha, I. I. Umanah, M. C. Ugonna and D. N. Nwaigwe, "Comparative-study of Compressive-strengths and Densities of Concrete Produced with different Brands of Ordinary Portland Cement in Nigeria", International Journal of Scientific \& Engineering Research, vol. 8, September 2017, pp.12601275.

[18] S. O. Banjo, B. O. Bolaji, O. Ibhadode, O. B. Fakehinde, P. S. Olayiwola, S. O. Oyedepo, and N. E. Udoye, "Experimental analysis of the performance characteristic of an eco-friendly HC600a as a retrofitting refrigerant in a thermal system", $J$. Phys.: Conf. Ser. 1378 (2019) 042033. DOI: 1088/1742-6596/1378/4/042033

[19] P.F. Achieng Ogola, "Environmental Impact Assessment General Procedures." Proceedings of the Short Course II on Surface Exploration for Geothermal Resources", United Nations University and Kenya Electricity Generating Company Limited, vol. 2, November 2007, pp.1-16.

[20]C. S. E. India, "Understanding EIA", C. S. E India Publications. Accessed online 14 $4^{\text {th }}$ November 2019, at https://www.cseindia.org/understanding-eia-383.

[21]333 Course E, "Environmental Impact Assessment", Environmental Management Module - 7. Accessed online 18 November 2019, at http://download.nos.org/333courseE/24.pdf

[22] D. J. Kalita, "Environmental Impact Assessment (EIA) in India: An Appraisal”, Dimorian Review, vol. 3, February 2016, pp.50-54.

[23] UK Essays, “Origin, History and Development of EIA”, Environmental Sciences Essay. Accessed online $1^{\text {st }}$ January 2020, at https://www.ukessays.com/essays/environmental-sciences/origin-history-and-development-of-eia-environmental-sciencesessay.php

[24] Federal Ministry of Environment, "Federal Environmental Protection Agency (FEPA) Publication", Federal Ministry of Environment Press, Abuja, Nigeria, 1995.

[25] DPR, "Environmental Guidelines and Standards for the Petroleum Industry in Nigeria", Department of Petroleum Resources, Lagos under the auspices of the Federal Ministry of Petroleum Resources, Abuja, Nigeria, 1991.

[26] DPR, "Environmental Guidelines and Standards for the Petroleum Industry in Nigeria", Department of Petroleum Resources, Lagos under the auspices of the Federal Ministry of Petroleum Resources, Abuja, Nigeria, 2001.

[27] ISO 1996-1 Standard: Acoustics-Description, Measurement of Environmental Noise-Basic Quantities and Assessment Procedures (2016)

[28] ISO 1996-2 Standard: Acoustics-Description, Measurement and Assessment of Environmental Noise-Determination of Environmental Noise levels (2016)

[29] World Health Organization (WHO), WHO Guidelines for Indoor Air Quality: Selected Pollutants, WHO Regional Office for Europe, 2010.

[30] K. A. Kershaw, Quantitative and Dynamic Plant Ecology, $2^{\text {nd }}$ ed., London, Edward Arnold, 1973.

[31] H. J. Oosting, The Study of Plant Communities: An Introduction to Plant Ecology, New York, W. H. Freeman \& Company, 1956.

[32] E. P. Odum, Fundamentals of Ecology, $3^{\text {rd }}$ ed., Philadelphia, Saunders, 1971.

[33] C. Raunkiaer, The Life Forms of Plants and Statistical Plant Geography, London, Oxford University Press, 1934.

[34] American Society for Testing and Materials (ASTM) International, "Standard methods for acidity or alkalinity of water", ASTM D1067-16, Conshohocken, Philadelphia, USA, 2016, pp.1-9. DOI: 10.1520/D1067-16.

[35] American Society for Testing and Materials (ASTM) International, "Standard methods lithium, potassium, and sodium ions in brackish water, seawater, and brines by Atomic Absorption Spectrophotometry", ASTM D3561-16, West Conshohocken, Philadelphia, USA, 2016, pp.1-6. DOI: 10.1520/D3561-16.

[36] Y. Meride and B. Ayenew, "Drinking water quality assessment and its effects on residents' health in Wondo genet campus, Ethiopia”, Environmental Systems Research, vol. 5, 2016, pp.1-7.

[37] American Society for Testing and Materials (ASTM) International, "Standard methods for calcium and magnesium in water", ASTM D511-14, West Conshohocken, Philadelphia, USA, 2014, pp.1-9. DOI: 10.1520/D0511-14.

[38] American Society for Testing and Materials (ASTM) International, "Standard methods for Nitrite-Nitrate in water", ASTM D3867-16, West Conshohocken, Philadelphia, USA, 2014, pp.1-11. DOI: 10.1520/D3867-16.

[39] L. S. Clesceri, A. E. Greenberg, and A. D. Eaton, "Standard methods for the examination of water and wastewater", American Public Health Association (APHA), 20th ed., Washington, DC, 1998, pp.2-3

[40] C. M. A. Ademoroti, Standard method for water and effluents analysis, Ibadan, Foludex press Limited, 1996, pp. $22-112$.

[41] Standards Organization of Nigeria (SON), "Nigerian Standard for drinking water quality", SON Publication, Abuja, Nigeria, 2007, pp. 15-16. 
[42] Nigerian Industrial Standard (NIS), "Nigerian Standard for drinking water quality", NIS Publication, Abuja, Nigeria, 2015, pp. 16-21.

[43] United States Environmental Protection Agency (USEPA), "Total coliforms and Escherichia coli in water by membrane filtration using a simultaneous detection technique (MI medium)", USEPA Method 1604, Washington, D. C., USA, 2002, pp.1-14.

[44] World Health Organization (WHO), "Guideline on standard operating procedures for microbiology", WHO Publication, Geneva, Switzerland, 2010.

[45] Richmond Consolidated School, "Results of Lead and Copper Testing", USEPA Notice of Tap water Test Results. Accessed online $18^{\text {th }}$ November 2019, at https://safewater.zendesk.com.en-us 